\title{
The importance of terms of trade in the Colombian economy
}

\author{
Andrés Felipe Oviedo Gómez and Lya Paola Sierra Suárez
}

\begin{abstract}
Commodities represent the lion's share of Colombia's exports, and the terms of trade are directly determined by the prices of these commodities, making a detailed analysis of this variable's impacts on the country's economy essential. This paper examines the effects of terms-of-trade shocks on output, investment, consumption, the trade balance, the real exchange rate and inflation in Colombia. An extensive database comprising 129 variables of economic activity in 2001-2016 was used, along with a FAVAR model. The results suggest that terms-of-trade shocks have significant impacts on the Colombian economy, as they explain roughly $5 \%$ of the variation in the country's economic activity, $8 \%$ in investment, $6 \%$ in the trade balance and $1 \%$ in the real exchange rate.
\end{abstract}

\section{Keywords}

Terms of trade, international trade, economic conditions, economic development, econometric models, Colombia

JEL classification

F14, F41, O54

\section{Authors}

Andrés Felipe Oviedo Gómez is a Professor at Universidad del Valle, Colombia. Email: oviedo.andres@correounivalle.edu.co.

Lya Paola Sierra Suárez is an Associate Professor in the Department of Economics at Pontificia Universidad Javeriana in Cali, Colombia. Email: lyap@javerianacali.edu.co. 


\section{Introduction}

The terms of trade represent the ratio of a country's export prices to its import prices, which indicates the purchasing capacity generated by exports. The exogenous nature of the terms of trade sheds light on the effects of external shocks on different economic sectors.

A large percentage of the exports of many developing countries, unlike those of industrialized countries, consists of raw materials or commodities, which makes them more vulnerable to terms-oftrade shocks. According to Fernández, González and Rodríguez (2015), the average percentage of commodities exported by developing countries is more than double that of industrialized countries. By their very nature, commodity prices are highly volatile because of relatively inelastic supply and demand ${ }^{1}$ in the short term (Sinnot, Nash and de la Torre, 2010). According to the same authors, terms-of-trade volatility is highest for fuel-exporting countries, followed by other commodity exporters and then by countries that specialize in manufacturing exports. The economic effects of terms-of-trade shocks do not depend solely on their magnitude and the type of product exported, but also on the openness of the economy to international markets. According to Ortiz (2016), since the 1990s several South American countries have implemented the neo-liberal model without diversifying production, which has increased these economies' exposure to external disturbances. As a result, these disturbances have had an immediate impact on public revenues and fiscal aggregates (World Bank, 2000).

Terms-of-trade shocks are especially significant for Colombia given that in 2015, exports accounted for $15 \%$ of GDP (World Bank, 2016) and commodities accounted for $80 \%$ of these exports. Oil (40\%), coal $(13 \%)$, coffee $(7 \%)$ and nickel (1\%) represented more than half of the country's exports. ${ }^{2}$

The aim of this paper is to quantify and explain the effects of terms-of-trade shocks on macroeconomic variables in Colombia, mainly output, investment, consumption, the trade balance, the real exchange rate and inflation. The methodology used combines vector autoregressive models and dynamic factor models. It was proposed by Bernanke, Boivin and Eliasz (2005) and is called the factor-augmented vector autoregressive (FAVAR) approach. The advantage of FAVAR models is that they use countless macroeconomic variables and eliminate the data limits of VAR models, which guarantees a broader analysis of the effects of terms of trade on economic activity. They also reduce the anomalies that could generate omitted-variable biases.

For this analysis, in addition to the above-mentioned variables, 129 quarterly macroeconomic series corresponding to 2001-2016 were used. Given the apparent absence until now of empirical research that employs FAVAR models, or that reflects such extensive use of economic variables in the analysis of terms-of-trade shocks, the main aim of this article is to provide a broader perspective of the relative importance of the terms of trade for different macroeconomic variables in Colombia.

After the introduction, the paper is divided as follows: section II includes a literature review of studies previously carried out at the international level and in Colombia; section III defines the terms of trade, explains how they are modelled and describes the trends they have reflected in recent years, as well as their link with the main macroeconomic variables in Colombia; section IV includes a description of the empirical methodology used; section $\mathrm{V}$ presents the data and section $\mathrm{VI}$ includes an analysis of the empirical results. Lastly, section VII presents the conclusions.

\section{Literature review}

This section describes the studies carried out by different authors on the impact of terms-of-trade shocks in developed and emerging economies for which commodities represent a large percentage of exports.

\footnotetext{
1 See Roberts and Schlenker (2013) for more information on supply and demand elasticity.

2 Information obtained from the National Administrative Department of Statistics (DANE).
} 
On the basis of the assumption that commodity-exporting countries are more likely to feel the effects of terms-of-trade shocks, several authors have observed that different economic aggregates such as GDP, investment, consumption and the exchange rate are the most affected variables, but the magnitude of the impact is determined by the economic characteristics of the country or by the methodology used. In the 1990s, Mendoza (1995) examined the relationship between terms of trade and business cycles, using a theoretical model applied to 23 developing countries and 7 industrialized countries. The results show that terms-of-trade shocks explain between 37\% and 56\% of the actual variability of GDP in developing countries, compared with 33\% in industrialized countries. Schmitt-Grohé and Uribe (2015) developed a model similar to that of Mendoza (1995) and estimated structural vector autoregression (SVAR) using data from 38 poor and emerging countries to evaluate the effect of the terms of trade. The theoretical model indicates that terms-of-trade shocks account for about $30 \%$ on average of the variation in output, consumption and investment in those countries. By contrast, the empirical results of the SVAR model point to a variation of roughly $10 \%$ in these aggregates. These results are consistent with those obtained by Broda (2004), who concluded, on the basis of an analysis of 75 developing countries, that terms-of-trade shocks account for less than $10 \%$ of real GDP volatility.

The evidence shows a greater impact of terms-of-trade shocks in developing countries which export mainly commodities, although the effect of variations in the prices of these products in oil-exporting developed countries is also significant. Andrews and Rees (2009) conducted a study to examine the effects of the terms of trade on the Australian economy and concluded that if the volatility of annual terms of trade growth was greater by one standard deviation, the volatility of shocks to annual GDP growth and annual inflation would be 1.1 percentage points and 1.2 percentage points greater, respectively. Meanwhile, Jääskelä and Smith (2013), also focusing on Australia, used a VAR model to observe the response of inflation, output, interest rates and exchange rates to three types of external terms-of-trade shocks. The results show that the terms-of-trade shocks explain two thirds of the variation in the real exchange rate, but less than one fifth of the variation in the other variables. On the basis of the same methodology used by Jääskelä and Smith (2013), Karagedikli and Price (2013) concluded that external terms-of-trade shocks explain around $20 \%$ of the fluctuations in GDP in New Zealand. In the case of Canada, Charnavoki and Dolado (2014) proposed a structural dynamic factor model to identify the main global shocks that drive world commodity prices. The results indicate that a positive global demand shock leads to an improvement of $0.04 \%$ in the terms of trade.

Latin America is especially likely to suffer from the effects of terms-of-trade shocks as most of its countries are dependent on commodities, which accounted for more than $80 \%$ of the region's total exports in 2014. According to Ben Zeev, Pappa and Vicondoa (2016) - on the basis of the theoretical model used in Schmitt-Grohé and Uribe (2015) and a VAR model - the terms of trade explain, on average, $25 \%$ of output fluctuations in both the theoretical and empirical models for Argentina, Brazil, Chile, Colombia, Ecuador, Mexico and Peru. Izquierdo, Romero and Talvi (2008) examined terms-of-trade fluctuations in Argentina, the Bolivarian Republic of Venezuela, Brazil, Chile, Colombia, Mexico and Peru, and concluded that an increase of almost two percentage points in the terms of trade generates an increase in GDP growth of just $0.21 \%$ in the second quarter following a shock. Meanwhile, Ahmed (2003) found that terms-of-trade shocks explain, on average, less than $8 \%$ of output fluctuations for Argentina, the Bolivarian Republic of Venezuela, Brazil, Chile, Colombia and Mexico. On the basis of a variance decomposition applied to Peru, Castillo and Salas (2012) concluded that terms-of-trade shocks explained approximately $90 \%$ of the fluctuations in output, investment and consumption at the 10-year horizon.

Despite the importance of the terms of trade in commodity-dependent economies, there are few studies on Colombia that evaluate the impact of terms-of-trade shocks on economic activity. In general, the effects of terms-of-trade shocks on macroeconomic variables are evaluated separately in specialized literature. For example, Arteaga, Granados and Joya (2013) analyse the impact of the terms of trade on the real exchange rate. Meanwhile, Gaviria (1993) examines the effect of terms-of-trade shocks on private saving, and Parra (2008) and Hernández (2013) evaluate the impact of fluctuations in the terms 
of trade on Colombia's GDP. It is important to highlight the work of Hernández (2013), who concluded that the terms of trade account for between $27 \%$ and $33 \%$ of the quarterly variability in GDP. Hence, although there are papers which analyse the impacts of the terms of trade on different variables, for the time being there are no studies which incorporate a broad set of variables that largely describe national economic activity or that evaluate the responses of these variables to fluctuations in the terms of trade. This research paper seeks to close this gap, using a FAVAR model which, unlike vector autoregressive models, allows the estimation of the dynamic responses of a large number of home variables to foreign shocks (Mumtaz and Surico, 2009). Moreover, it aims to provide an alternative to the disconnect between the theoretical and empirical models, as outlined by Schmitt-Grohé and Uribe (2015) and Aguirre (2011), who advise the application of another methodology that guarantees a better interpretation of data.

\section{Terms of trade and the Colombian economy}

What follows is a descriptive analysis of the terms of trade in Colombia and the variables most affected by terms-of-trade shocks, by authors such as Hernández (2013), Schmitt-Grohé and Uribe (2015) and Castillo and Salas (2012).

The data that will be used to model the terms of trade derive from the index developed by the central bank (Bank of the Republic) using implicit prices and based on the methodology of the chained Paasche index proposed by Garavito and others (2011). Equation (1) shows the general structure of the terms-of-trade index (ITI) through the ratio of the chained Paasche index of export prices $\left(I P_{X, t}\right)$ to that of import prices $\left(I P_{M, t}\right)$ for the period $t$ :

$$
I T I_{t}=\left(\frac{I P_{X, t}}{I P_{M, t}}\right) \cdot 100
$$

On the basis of this methodology, figure 1 shows the terms-of-trade index of Colombia. The most significant piece of information shown in the figure is the improvement in the terms of trade from the 2000 decade onward. According to authors such as Jenkins (2011) and Sierra (2015), this derived from the boom in commodity prices resulting from the increase in demand from China and India and the decline in global manufactured goods prices in the first decade of the twenty-first century. Most Latin American countries became the largest suppliers for Asian countries as a result of this strengthening of their terms of trade. The figure also shows a deterioration in the terms of trade in mid-2008 owing to the global financial crisis, and another decline in 2014 stemming from the sharp drop in oil prices.

Figure 1

Colombia: terms-of-trade indices, 1995-2016

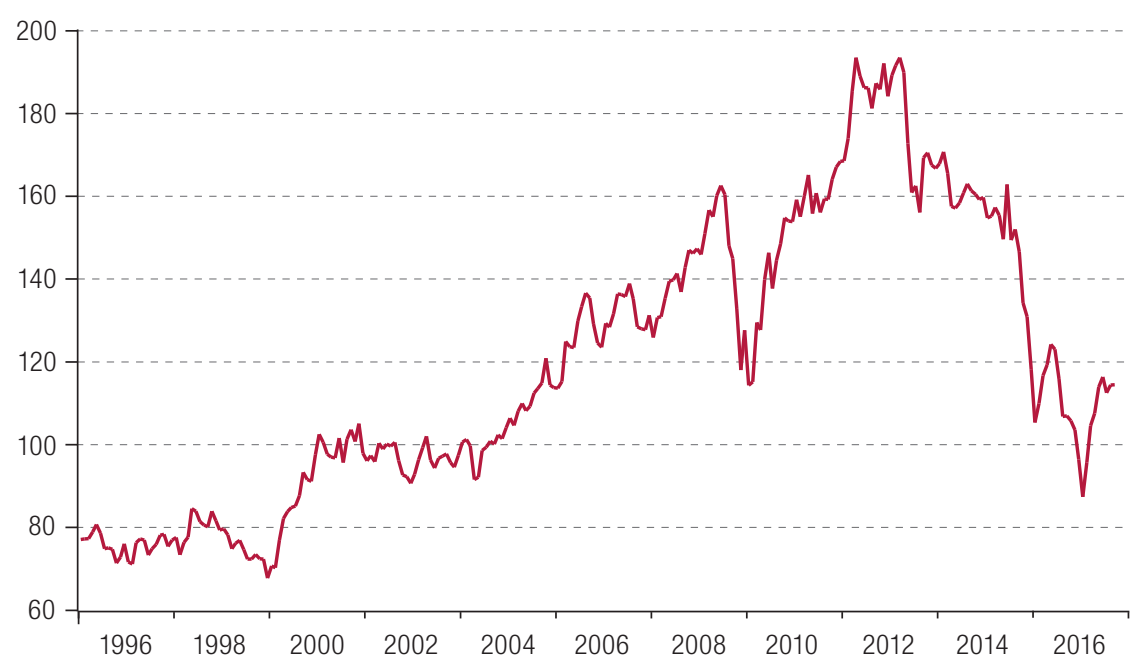

Source: Bank of the Republic of Colombia, 2016. 
Given the large share of commodities in Colombia's exports, the relationship between the prices of these commodities and the terms of trade is analysed graphically. Figure 2 shows the prices of coffee $^{3}$ (dashed line) and of oil (solid line) in Colombia in 1980-2016. These products are highlighted because they have accounted for the largest share of Colombian exports in the past few decades. Coffee became a symbol of the national economy in the 1970s thanks to the coffee bonanza, as it represented more than 50\% of total exports (60\% in the late 1970s) (Cano and others, 2012). Between 1980 and 2016 we compute a correlation of 0.57 between the terms-of-trade index and coffee prices, compared with 0.37 with regard to oil prices. Nonetheless, the share of oil in total exports rose sharply in the mid-1990s, and since 1995, oil has been Colombia's main export. In the past three decades (1995-2016), we have calculated a positive correlation of 0.88 between the terms of trade and oil prices, compared with 0.65 with regard to coffee prices. This indicates that fluctuations in the oil price now play an important role in the evaluation of the terms of trade in Colombia.

Figure 2

Oil and coffee prices, 1980-2016

(US\$ per barrel and per pound)

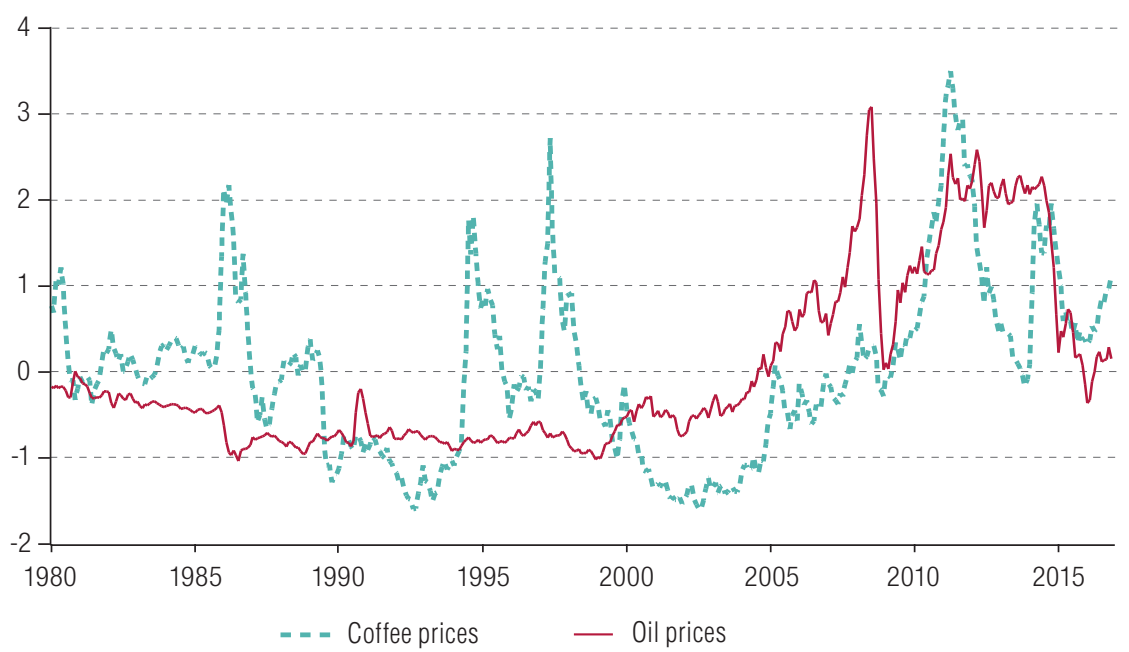

Source: International Monetary Fund (IMF).

With regard to the other commodities exported by Colombia, such as coal and nickel, we have calculated correlation of these prices to the terms of trade of 0.7 and 0.4 for the period between 1980 and 2016, respectively.

According to the above-mentioned literature, the terms of trade also affect the following variables: GDP, investment (gross fixed capital formation), total consumption, the trade balance, the real exchange rate index and total inflation. Figure 3 shows the trends in these variables in recent years. In the period between 2001 and 2016, our calculation of the correlation between the terms of trade and these variables reveals a positive value of 0.5 for GDP, which is close to the 0.35 determined by Hernández (2013). There is also a positive correlation between the terms of trade and investment (0.59) and consumption (0.54). According to Parra (2008), terms-of-trade shocks result in stronger investment and consumption owing to the reallocation of capital to productive areas. Meanwhile, we computed a high positive correlation of 0.82 between the terms of trade and the trade balance, and a negative correlation of 0.9 between the terms of trade and the real exchange rate index. This result is in line with that obtained by Poncela, Senra and Sierra (2017) who concluded, for example, that the income derived

3 Coffee prices correspond to the cash price of Colombian mild arabica, of the International Coffee Organization, New York, in US\$ per pound.

4 Oil prices correspond to the simple average of three spot prices: Dated Brent, WTI and Dubai Fateh, in US\$ per barrel. 
from stronger oil prices generates an influx in foreign currency that in turn causes the real appreciation of the peso versus the dollar. Lastly, our calculation of the correlation between the terms of trade and inflation reflects a negative value of -0.7 .

\section{Figure 3}

Trend in variables, 2001-2016

A. GDP

(Billions of pesos, constant at 2005 prices)
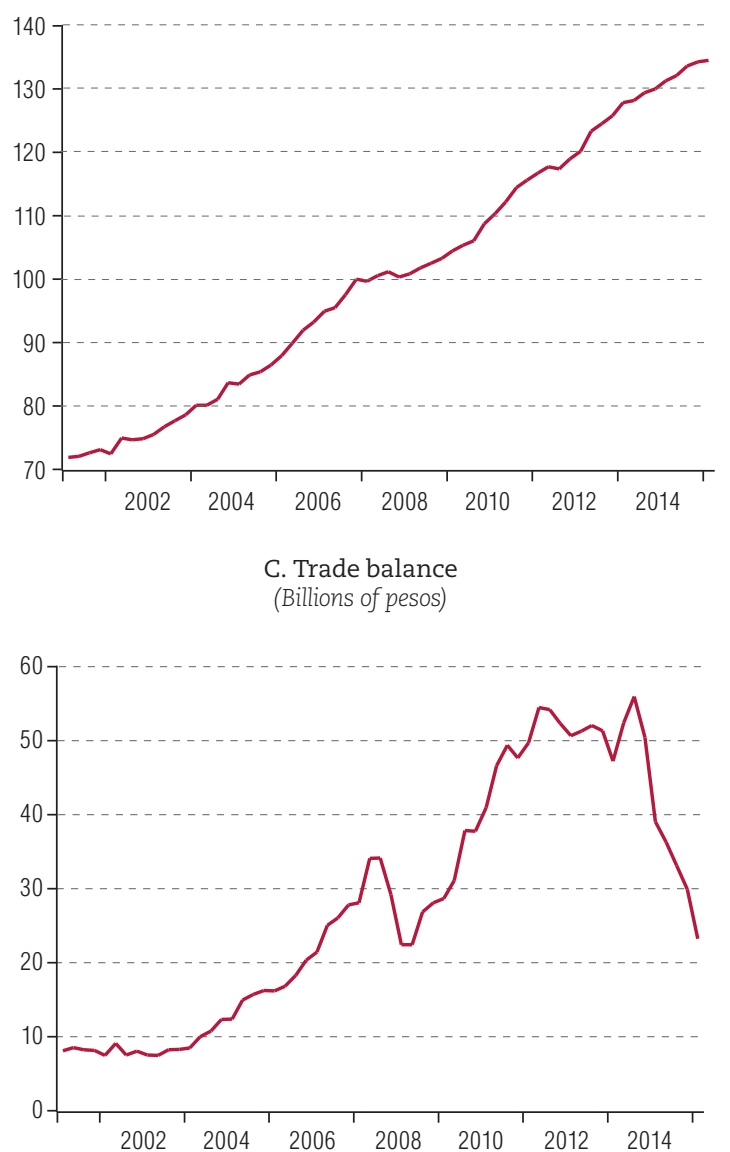

E. Inflation

(Year-on-year variation in consumer price index)

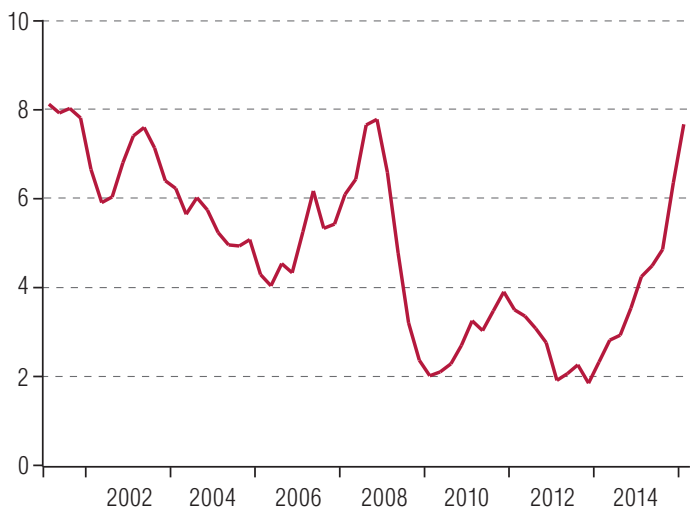

B. Investment Gross fixed capital formation (Billions of pesos)

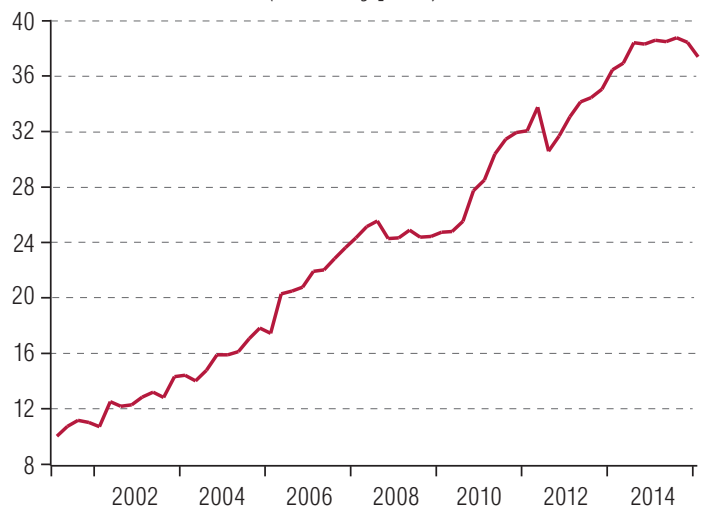

D. Real exchange rate index $(2010=100)$ (With respect to 18 International Monetary Fund (IMF) member countries)
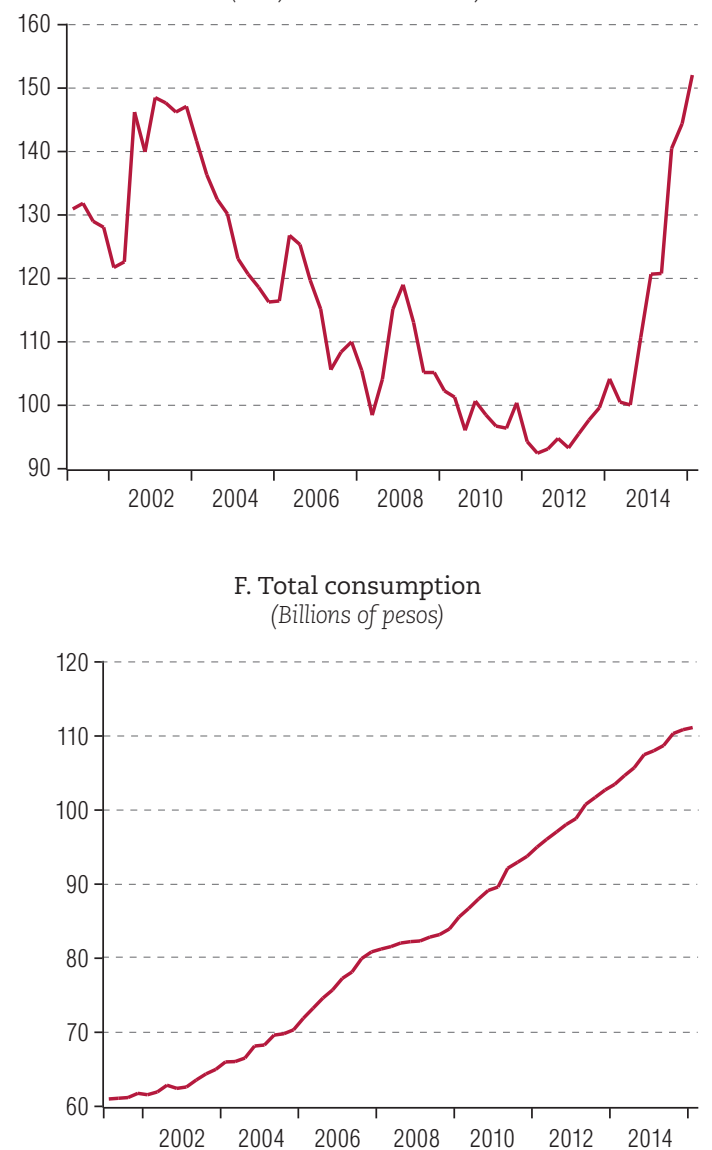

Source: Bank of the Republic of Colombia and National Administrative Department of Statistics (DANE). 
The impact of a positive terms-of-trade shock on each variable is explained below.

Given the relationship between the terms of trade and the different economic aggregates in Colombia, and in light of their exogenous nature, a positive terms-of-trade shock owing to, for example, stronger export (commodity) prices generates inflows of foreign currency into the country. This in turn incentivizes applications for credit, especially in the sector benefiting from the boom, in this case commodities, and favours investment as a result. Stronger inflows of foreign currency boost all sectors that produce commodities (directly and indirectly) and consumption, and as indicated by Hernández (2013), increase financial sector profits and government income (higher tax revenues). The local currency appreciates in real terms, first because of nominal appreciation owing to foreign currency inflows, and second because of higher prices resulting from stronger aggregate demand. An indirect negative effect, which has been overlooked often in the analysis of terms-of-trade impacts, is the weight of the real appreciation of local currency on the competitiveness of the export sector, which leads to a decline in value added and employment in these sectors (see Sierra and Manrique, 2014; Peláez and Sierra, 2016). The methodology proposed for this study incorporates all interactions of the economy with positive and negative effects, depending on the sector, in the face of a positive terms-of-trade shock, and determines the net impact of the shock on the overall economy.

\section{Methodology}

The following section describes the empirical methodology used to observe the effect of terms-of-trade shocks on different national macroeconomic variables. The FAVAR methodology of Bernanke, Boivin and Eliaz (2005) is employed, as it can be used to evaluate the persistence of exogenous shocks over time through the impulse response functions of a large number of macroeconomic variables. Unlike VAR models, it incorporates factors that provide enough information to broadly capture and identify the simultaneous movements of economic activity. It also partly reduces dimensionality problems.

\section{FAVAR models}

$Y_{t}$ is an $M x 1$ vector of economic variables that are observable or of interest: terms of trade, output, investment, consumption, trade balance, exchange rate and inflation, for $t=1,2, \ldots T$ periods. It can be concluded, as is normally the case with VAR models, that there is additional information not fully captured by $Y_{t}$ and that may be relevant to modelling the dynamics of this series. Nonetheless, this set of data that is excluded because of the limits of the empirical model can be summarized by a $K x 1$ vector of unobservable factors, $F_{t}$. The $\left(F_{t}, Y_{t}\right)$ dynamic may be represented by a VAR model, as shown in the following equation (2):

$$
\left[\begin{array}{l}
F_{t} \\
Y_{t}
\end{array}\right]=\Phi(L)\left[\begin{array}{c}
F_{t-1} \\
Y_{t-1}
\end{array}\right]+v_{t}
$$

where $\Phi(L)$ is a conformable lag polynomial of finite order $d$, and the error term, $v_{t}$, is mean zero with covariance matrix $Q$.

To estimate the factors, $F_{t}$, dynamic factor models - originally proposed by Geweke (1976) and developed extensively by Stock and Watson $(2002,2005,2011)$ - are used. The static representation of these models is as follows:

$$
X_{t}=\Lambda F_{t}+e_{t}
$$


where $X_{t}$ is an $N x 1$ vector that contains a broad data set (129 observable time series, which do not include the variables of interest). It is assumed that this vector of information $X_{t}$ can be represented as the sum of two unobservable components: one or some components common to all variables, $F_{t}$, and an idiosyncratic component, $e_{t}$, specific to each variable. In equation (3), $\Lambda$ is an $N x K$ matrix of factor loadings (the term $\Lambda F_{t}$ refers to common components of $X_{t}$ ) and the error term, $e_{t}$, is mean zero with normal distribution, with dimension $N x 1$. This last term may present weak cross-correlation to the extent that it captures the idiosyncratic component. ${ }^{5}$

In keeping with Bernanke, Boivin and Eliasz (2005), the FAVAR model is based on a two-step estimation method: the first step consists of the estimation of the spaces spanned by the factors, through $k$ principal components of $X_{t}$, and the second step involves the estimation of the equation (2) through the standard vector autoregressive method, which requires the replacement of $F_{t}$ with $\hat{F}_{t}$ (estimated factors). This method is characterized by its computational simplicity and strong robustness for cross-correlation in the error component (Stock and Watson, 2005). Forni and others $(2000,2005)$ demonstrate the coherence of the principal component predictor when the number of series $N$ and the dimension $T$ tend to infinity. Meanwhile, Bai and $\mathrm{Ng}$ (2002) state that the estimates are coherent when $\min \{N, T\}$ is 40 or larger.

The information criteria proposed by Bai and $\mathrm{Ng}$ (2002) are used to determine the number of factors to include in the second step. The generalized impulse response functions proposed by Pesaran and Shin (1998) are also estimated: unlike the impulse response functions determined by the Cholesky method, these are invariant to the ordering of the variables in the VAR.

\section{Data}

The database used comprises the variables mentioned previously (terms of trade, output, investment, consumption, trade balance, exchange rate and inflation) and 129 macroeconomic series that represent different categories of the Colombian economy. The number of variables per category is indicated in parentheses: economic activity (23), external sector (23), real exchange rate (5), prices (31), monetary aggregates (16), total national employment (6), non-financial public sector (7), foreign investment inflows into Colombia (12) and interest rates (6). The study includes a balanced panel composed of quarterly data for 2001-2016. The period was selected first on the basis of the availability of data with no methodological changes and because it excludes the turning point in the 1990s of the opening of Colombia's economy, which increased exposure to external shocks. The period following 2001 is also interesting as it includes the impact on Latin American countries' terms of trade when China became a member of the World Trade Organization (WTO) in 2001, as indicated in section III. The period was characterized by the strong growth of Asian economies, mainly China, which boosted the terms of trade of Latin American countries (Sierra, 2015).

Before transforming the series, outliers were eliminated, in keeping with Stock and Watson (2002), who state that those data change the estimation method of the estimated factors for principal components, as they significantly increase the value of variance. Therefore, time series regression with ARIMA noise, missing values and outliers, developed by Gómez and Maravall (1998), is used to automatically detect outliers. This method uses specification: $\ln X_{i, t}=\frac{\theta_{i}(B)}{\Delta \phi_{i}(B)} \varepsilon_{i t}+$ outliers, where $\Phi_{i}(B)$ is an autoregressive polynomial of order $p_{i}, \theta_{i}(B)$ is a moving-average polynomial of order $q_{i}$ with the backwards operator $B$ and $\Delta$ is the differencing operator $(1-B)$.

\footnotetext{
5 Both $F_{t}$ and $e_{t}$ can follow an autoregressive process, although this is not taken into account in this study.
} 
The model described in section IV explains that the $X_{t}$ variable matrix must be stationary, and thus before the estimation of the model a unit root test was carried out with intercepts and trends, using the tests suggested by Dickey and Fuller (1979) and Phillips and Perron (1988). Annex A1 includes information on the variables of interest and the 129 series used and their respective transformations. Lastly, after being converted to stationary, the series are standardized to reflect sample mean zero and variance equal to one, in keeping with Stock and Watson (2011).

\section{Empirical results}

This section describes the results obtained from the estimation of the FAVAR model (equation (2)) outlined in section IV. The estimation defined $Y_{t}$ observable variables and extracted $F_{t}$ unobservable factors of the 129 remaining series. This section is divided into four subsections: estimation of factors, impulse response functions, variance decomposition and robustness tests.

\section{Estimation of the number of factors}

Of the three penalty functions proposed by Bai and $\mathrm{Ng}$ (2002), the first two include four factors, while nine factors are used in the third. Table 1 summarizes the results of the information criteria.

Table 1

Number of estimated factors using the information criteria of Bai and Ng (2002)

\begin{tabular}{llcccc}
\hline Sample & Period & Number of observations & $I C_{I}$ & $I C_{1}$ & $I C_{I}$ \\
\hline Complete & First quarter of 2001 to first quarter of 2016 & 61 & 4 & 4 & 9 \\
\hline
\end{tabular}

Source: Prepared by the authors

Note: IC stands for information criteria.

As indicated, the first principal component is chosen from the block of remaining variables (129) and through the analysis of the principal components. It explains approximately $18 \%$ of the variance of this group, as outlined in table 2, and is labelled factor 1 or real exchange rate, owing to its weight in the series and the correlation of 0.7 with the real exchange rate index. The following factor accounts for approximately $16 \%$ of variance and is labelled factor 2 or monetary aggregates, owing to its weight in monetary aggregates and the positive correlation of 0.7 with the $\mathrm{M} 1$ variable. Meanwhile, factor 3 , which explains roughly $13 \%$ of variance, corresponds to prices in light of the positive correlation of 0.5 with the series of the consumer price and producer price indices. Factor 4, which accounts for roughly $10 \%$ of variance, refers to the economic activity resulting from the positive correlation of 0.5 with the consumption and GDP growth variables. The first four factors described account for roughly $57 \%$ of total variance. Each factor from number five onward explains less than $5 \%$ of variance, which supports the selection of four factors. 
Table 2

Factors derived from the analysis of principal components

\begin{tabular}{cccccc}
\hline Factor number & Value & Difference & Proportion & Cumulative value & Cumulative proportion \\
\hline 1 & 18.117920 & 2.40323 & 0.1342 & 18.11792 & 0.1342 \\
\hline 2 & 15.714690 & 2.41727 & 0.1164 & 33.83262 & 0.2506 \\
\hline 3 & 13.297420 & 3.52985 & 0.0985 & 47.13004 & 0.3491 \\
\hline 4 & 9.767571 & 3.08406 & 0.0724 & 56.89761 & 0.4215 \\
\hline 5 & 6.683512 & 0.945658 & 0.0495 & 63.58112 & 0.4710 \\
\hline 6 & 5.737855 & 0.587268 & 0.0425 & 69.31898 & 0.5135 \\
\hline 7 & 5.150586 & 0.624079 & 0.0382 & 74.46956 & 0.5516 \\
\hline
\end{tabular}

Source: Prepared by the authors.

\section{Impulse response functions}

Figures 4, 5 and 6 show the results of the estimation of accumulated impulse responses to generalized positive shocks in the terms of trade index $\left(T T I_{t}\right)$ for three observable macroeconomic series (investment, $I_{t}$; trade balance, $T B_{t}$; and total consumption, $C_{t}$ ) with a 95\% confidence interval and over a period of 10 quarters. This involves the selection of four factors (real exchange rate, monetary aggregates, prices and economic activity) and three lags, given that the model is robust and consistent in the evaluation of the assumptions for residuals (see annex A2). The results reveal a significant positive effect of the terms of trade on economic activity (factor simulating GDP), investment and the trade balance. By contrast, with regard to the real exchange rate (factor simulating the real exchange rate index) a significant negative effect is observed, while for prices (factor representing inflation) and total consumption, the impact is insignificant.

Figure 4

Accumulated impulse response of economic activity and investment to generalized one standard deviation innovations in the terms-of-trade index

A. Accumulated response of economic activity to terms-of-trade innovations

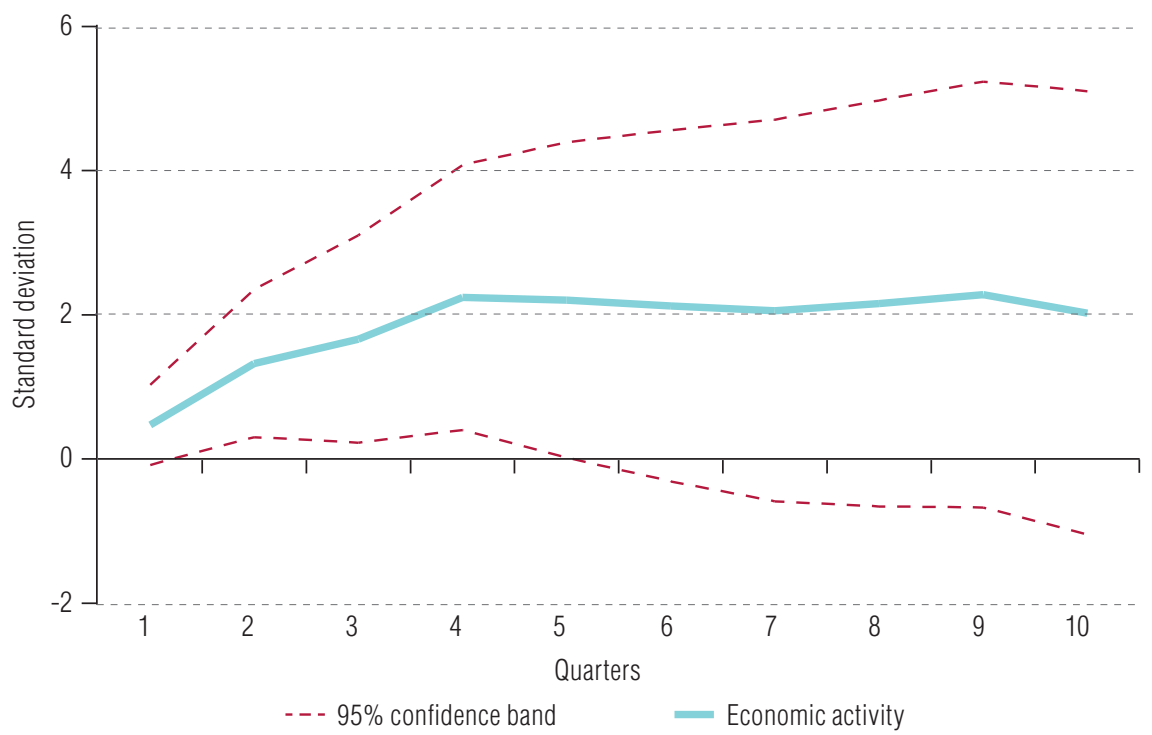


Figure 4 (concluded)

\section{B. Accumulated response of investment to terms-of-trade innovations}

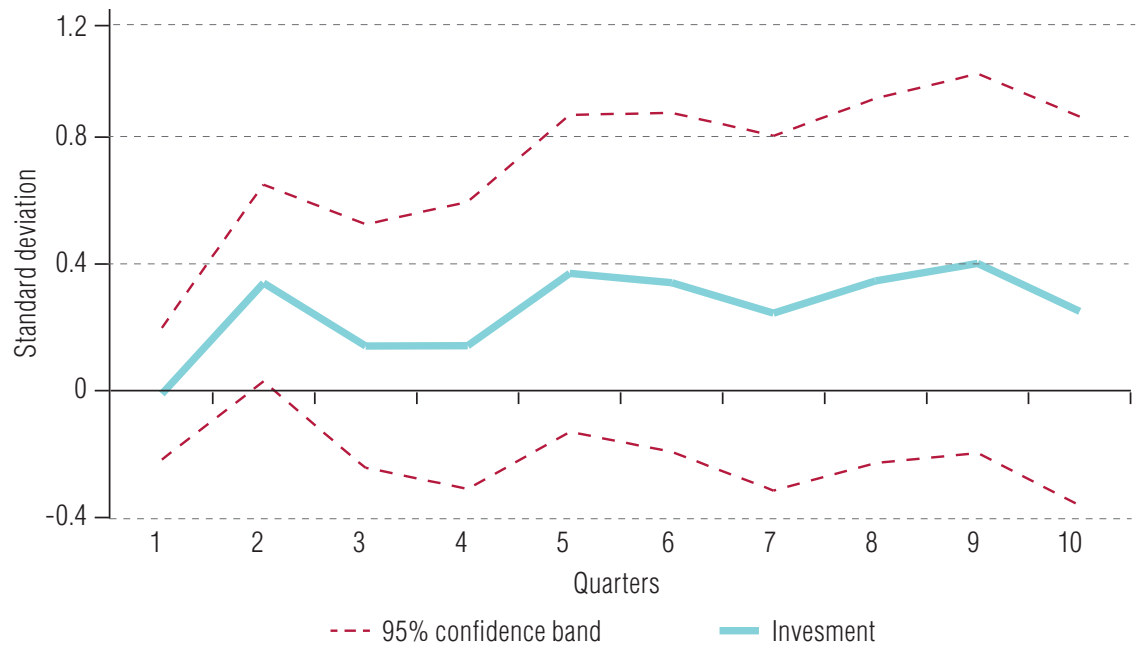

Source: Prepared by the authors.

Figure 5

Accumulated impulse response of the trade balance and real exchange rate to generalized one standard deviation innovations in the terms-of-trade index

\section{A. Accumulated response of the trade balance to terms-of-trade innovations}

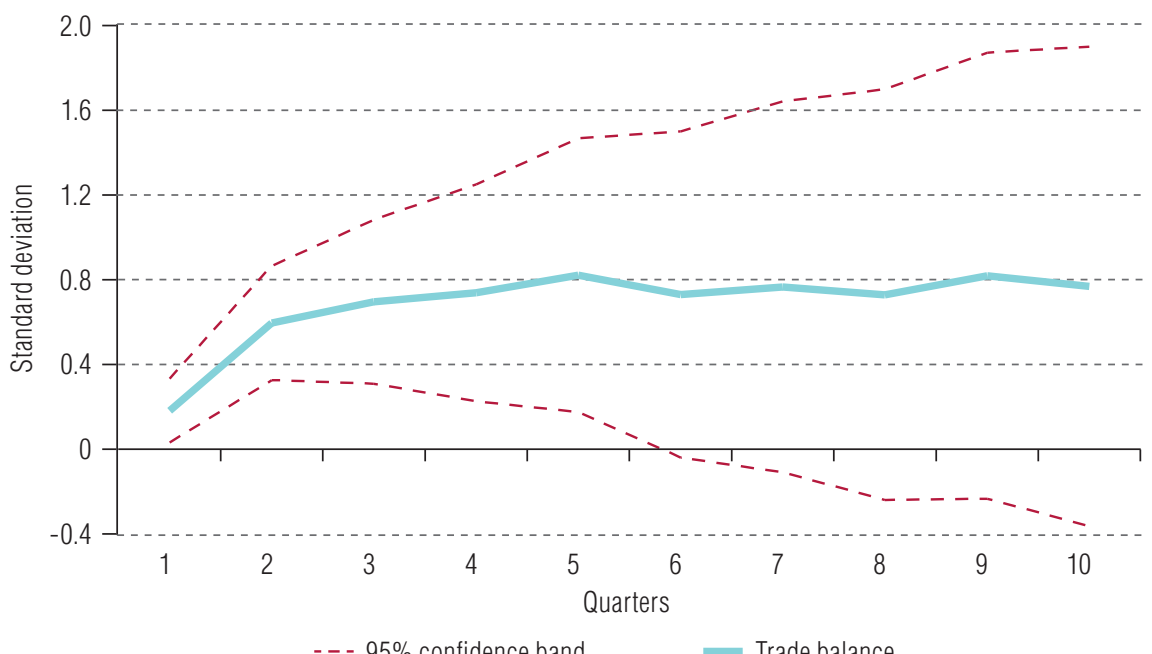

- - - 95\% confidence band $=$ Trade balance 
Figure 5 (concluded)

B. Accumulated response of the exchange rate to terms-of-trade innovations

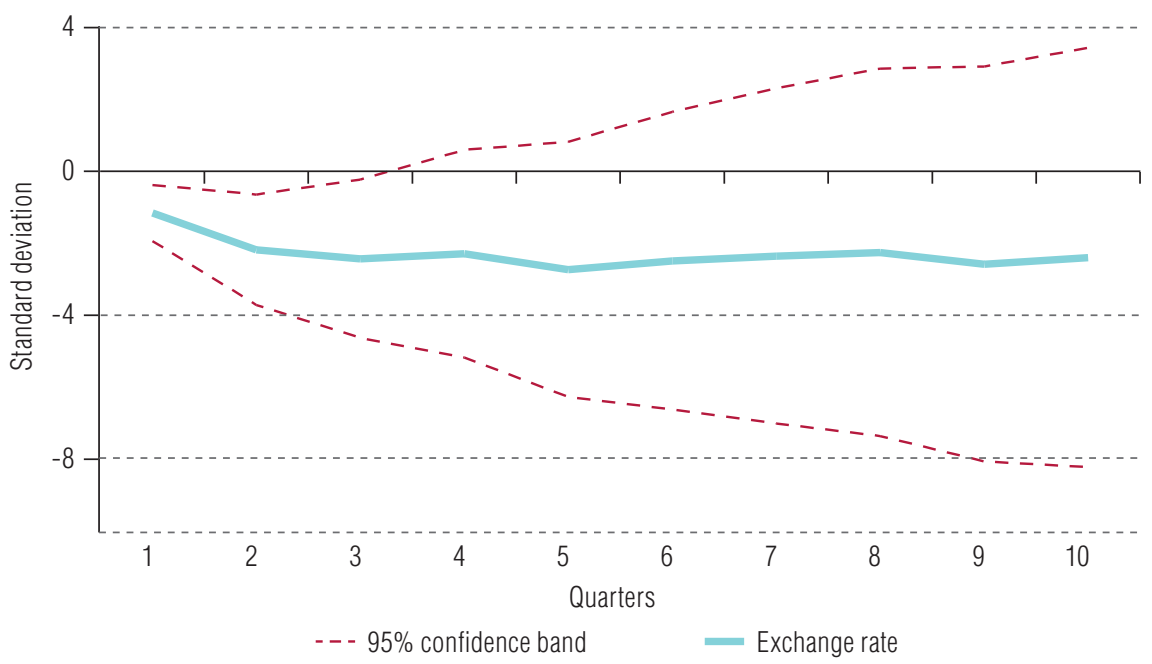

Source: Prepared by the authors.

Figure 6

Accumulated impulse response of monetary aggregates, prices (inflation) and total consumption to generalized one standard deviation innovations in the terms-of-trade index

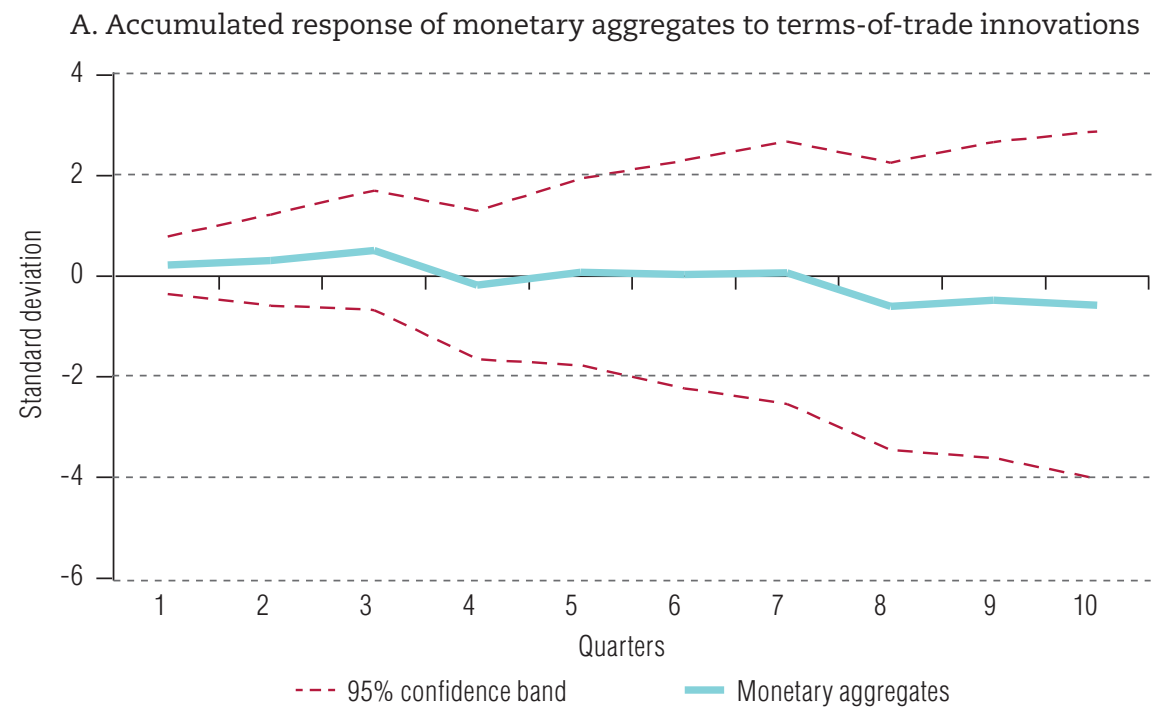


Figure 6 (concluded)

B. Accumulated response of prices to terms-of-trade innovations

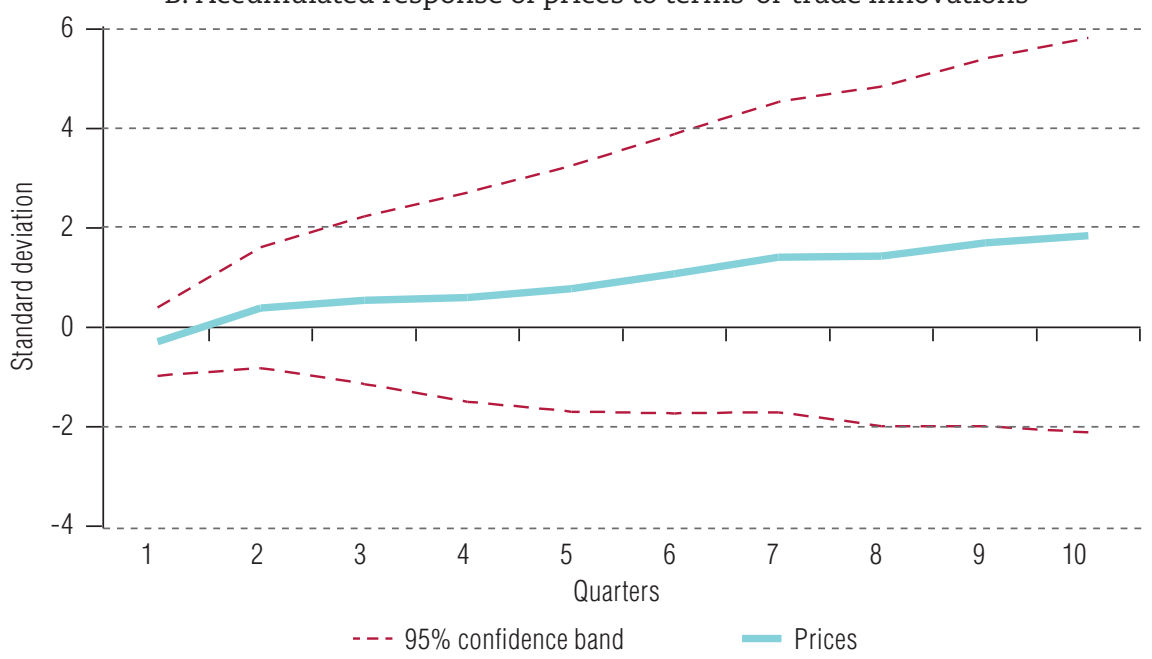

C. Accumulated response of total consumption to terms-of-trade innovations

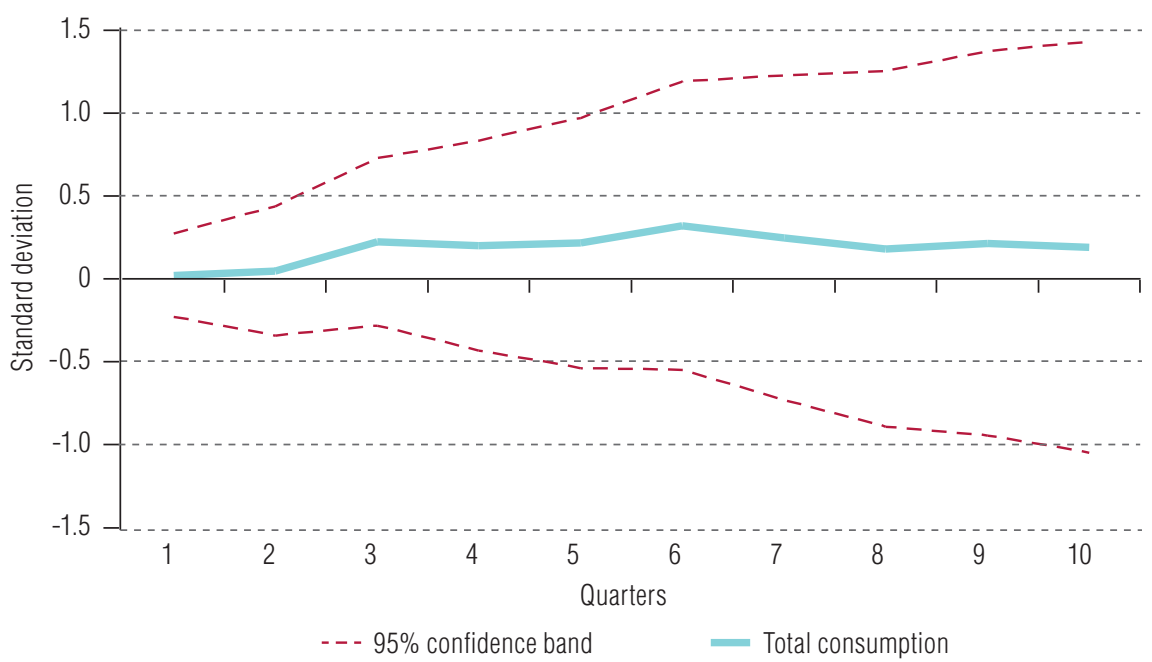

Source: Prepared by the authors.

In general, responses are coherent and comprehensible and based on economic theory, but different from the results obtained by other authors in terms of the magnitude of the impact. With regard to economic activity, the results suggest that a positive shock affecting the terms-of-trade index begins to be significant from the first quarter and lasts for a total of four. If the positive shock in the terms of trade derives from stronger export prices, the increase in economic activity resulting from that shock can be considered temporary, not permanent, as explained by Parra (2008). With regard to investment, the response is considered significant in the second quarter, but the effect of the shock lasts only a short while, just one quarter. This can be explained by the fact that the positive terms-of-trade shock directly and favourably affects the country's output through the trade balance, which boosts income and subsequently investment. In other words, investment is subject to the terms-of-trade impact through variations in output or income. 
Meanwhile, the impact on the trade balance is significant and positive, and lasts approximately five quarters from the beginning of the shock onward. This effect is the result of the positive terms-of-trade shock triggering an increase in the domestic production of exported goods. Observation of the real exchange rate indicates an inverse and prolonged response (approximately three quarters), which results in appreciation of the local currency versus the dollar because of strong foreign exchange inflows into the country. The short-term effect of this appreciation on manufacturing sectors depends on the exposure of each sector to external markets and the composition of inputs (imported or domestic). According to Sierra and Manrique (2014) and Peláez and Sierra (2016), the real appreciation of the peso negatively affected $50 \%$ of industrial value added (18 sectors) and $31 \%$ of total employment (18 sectors) in 2000-2010. Meanwhile, it positively affected 4\% of total value added (4 sectors) and $3 \%$ of total manufacturing employment (7 sectors). Nonetheless, this appreciation had no significant impact on 38 sectors that account for $45 \%$ of the total value added of manufactured goods or on 34 sectors that represent $66 \%$ of the total employment in the manufacturing sector.

Lastly, an analysis of the remaining factors, monetary aggregates, prices and total consumption, leads to the conclusion that a terms-of-trade shock does not have a significant impact on those variables. This is supported by Parra (2008), who found that the effects of terms-of-trade shocks in the 2000 decade resulted in appreciation of the local currency given the revaluation of the dollar that lasted until 2008. After analysing consumption, he inferred that the terms-of-trade shocks did not alter aggregate price levels. This means that the increase in oil prices in 2003-2014 and the strong appreciation of the peso did not give way to inflation. Therefore, it is important to highlight that inflation is not triggered by external shocks in this particular case.

Overall, the results show that the terms of trade have a significant impact on a set of macroeconomic variables, which largely summarize the behaviour of economic activity coherently and in line with expectations.

\section{Variance decomposition}

Error variance decomposition indicates how much movement in a series derives from specific innovations compared with those relating to the other variables included in the model. In other words, this methodology captures the different components that help to isolate the percentage change in each variable because of the innovation, which makes it easier to identify the relative dependence of each variable on the rest. The method used is Cholesky orthogonalization applied to FAVAR residuals.

Cholesky decomposition assumes the ordering of variables according to their degree of contemporaneous endogeneity. The variables are thus organized from most endogenous to most exogenous as follows: economic activity, total consumption, investment, prices, monetary aggregates, trade balance, real exchange rate and terms-of-trade index. In the case of Colombia we assume exogeneity in the terms of trade, for three reasons: Colombia is a relatively small open economy that does not influence international prices; as indicated in section III, there is a strong correlation between the terms of trade and oil prices, which are determined at the international level; and lastly, there is a study that demonstrates the exogeneity of the terms of trade of Latin American countries (see Ben Zeev, Pappa and Vicondoa, 2016).

The results of the variance decomposition with a finite horizon of 20 quarters are summarized in table 3 . They show that $5 \%$ of the variability of economic activity is explained by changes in the terms of trade. Consumption and monetary aggregates also reflect variability of $5 \%$. Meanwhile, variability of the trade balance, prices and the real exchange rate are $6 \%, 4 \%$ and $1 \%$, respectively. Lastly, investment reflects variability of $8 \%$ owing to changes in the terms of trade. 
Table 3

Variance decomposition of selected variables of interest

\begin{tabular}{lc}
\hline Variables & Percentage of variance explained by the terms of trade \\
\hline Economic activity (GDP) & 5.00 \\
\hline Total consumption & 5.00 \\
\hline Monetary aggregates & 5.00 \\
\hline Trade balance & 6.00 \\
\hline Prices (inflation) & 4.00 \\
\hline Real exchange rate & 1.00 \\
\hline Investment & 8.00 \\
\hline
\end{tabular}

Source: Prepared by the authors.

Investment is undoubtedly the variable most affected by terms-of-trade shocks, and accounts for one quarter of GDP. An improvement in the terms of trade boosts investment, especially in the commodity export sector, because marginal profitability is a function of projected export prices. Our results are not in line with those obtained for other countries by authors such as Castillo and Salas (2012), according to whom terms-of-trade shocks explain roughly $90 \%$ of fluctuations in output, investment and consumption at the 10-year horizon for the Peruvian economy. Hernández (2013) concluded that $27 \%-30 \%$ of variations in Colombian output were explained by the terms of trade. Meanwhile, Arteaga, Granados and Joya (2013) determined that an increase in terms of trade caused a decline of 50\% in the real exchange rate. Although our results coincide with those of other studies relating to the effects of the terms of trade on variables, the magnitude of the impact is smaller.

For authors such as Hernández (2013), Schmitt-Grohé and Uribe (2015) and Broda (2004), the magnitude of the impact of terms-of-trade shocks on different economic aggregates varies significantly, owing mainly to the methods used. Simulation-based models, such as the one developed by Mendoza (1995), indicate that terms-of-trade shocks have significant impacts on the economic activity of the countries reviewed, while VAR models reveal similar but smaller effects. It is argued that the disconnect between the two methodologies is the result of the scarcity of data or of the lags used in the empirical models. In other words, the model suffers from lag-truncation bias (Chari, Kehoe and McGrattan, 2008). The main advantage of FAVAR models, as an alternative to the methods mentioned previously, is the use of a large number of variables of economic activity, which allows them to capture more of the indirect effects of terms-of-trade shocks on economic activity. According to Stock and Watson (2005), FAVAR models reduce the probability of omitted variables, a common problem encountered with SVAR models, so the inclusion of a large number of economic series favours estimates by covering most structural shocks to an economy. In this study, the four estimated factors explain roughly $60 \%$ of the variance of the economic series used.

\section{Robustness tests}

In the following robustness test, the economic activity and real exchange rate factors have been replaced by GDP (measured in trillions of pesos, constant at 2005 prices) and by the real exchange rate index measured for 18 IMF member countries, respectively. The estimation of impulse response functions is shown in figure 7, and indicates that a positive shock for the terms-of-trade index has a favourable and significant impact on GDP, but this does not last as long as that of economic activity. Meanwhile, investment reflects two significant positive effects, one in the second quarter and the other in the fifth quarter, both of a short duration. The trade balance reacts positively and significantly for a longer period 
than in the previous model, while the response of the real exchange rate index is the same as that of the estimated real exchange rate, albeit shorter. Lastly, monetary aggregates, prices and total consumption do not reflect any significant changes in light of a terms-of-trade shock, as shown in the previous results. In short, on the basis of the estimates of impulse response functions following the replacement of the economic activity and real exchange rate factors with the corresponding series, it can be inferred that there is no significant difference compared with the main model described.

\section{Figure 7}

Accumulated impulse response of GDP, investment, the trade balance, the real exchange rate index, monetary aggregates, prices and total consumption to generalized one standard deviation innovations in the terms-of-trade index

\section{A. Accumulated response of GDP to terms-of-trade
index innovations}

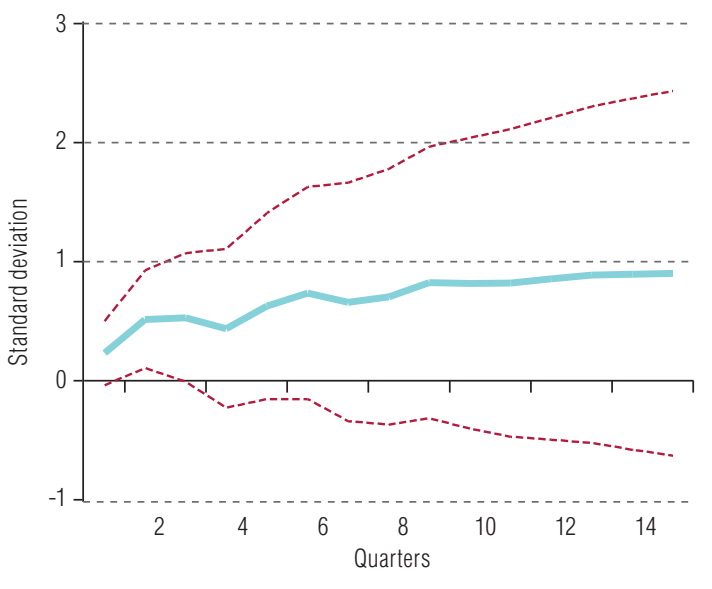

- - - 95\% confidence band GDP

C. Accumulated response of the trade balance to terms-of-trade index innovations

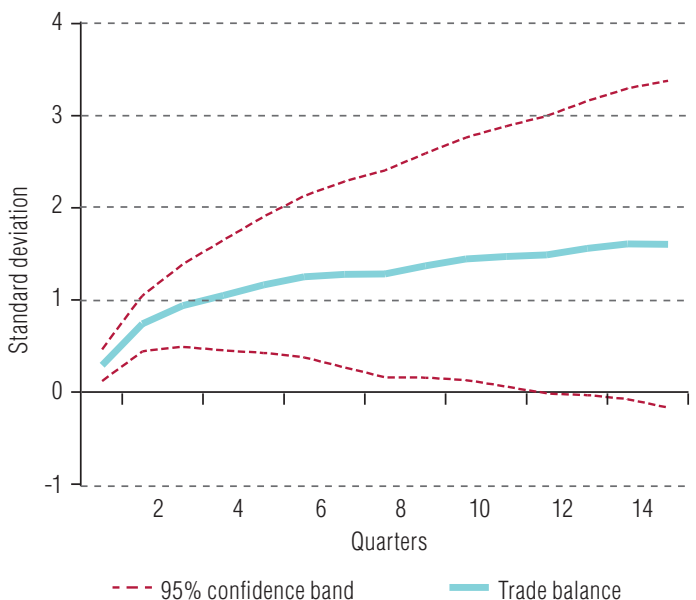

- - - 95\% confidence band $\quad$ Trade balance
B. Accumulated response of investment to terms-of-trade index innovations

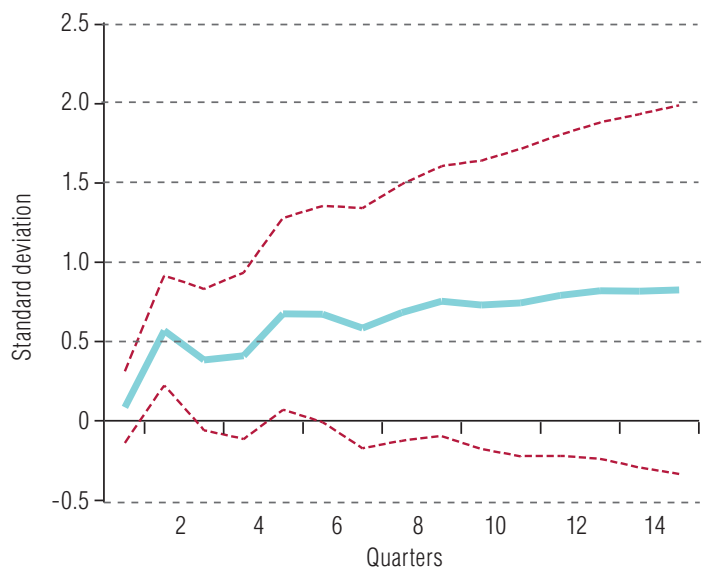

- - - 95\% confidence band Investment

D. Accumulated response of the real exchange rate index to terms-of-trade index innovations

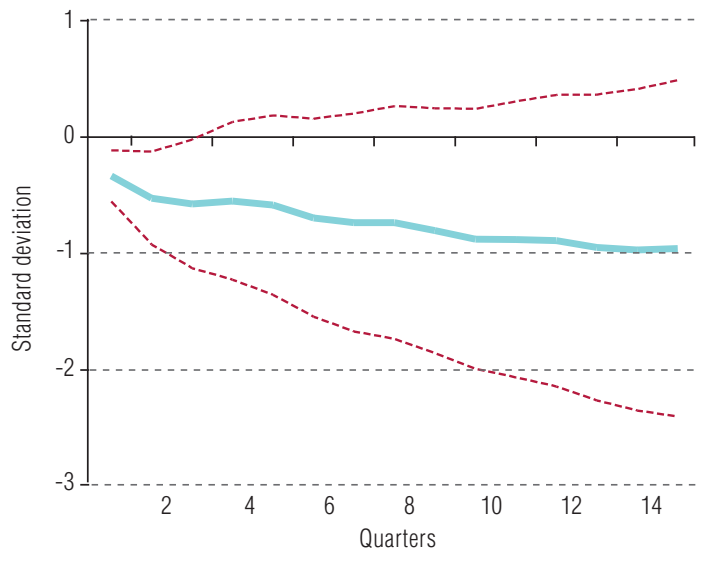

- - - 95\% confidence band $\quad$ Real exchange 
Figure 7 (concluded)

E. Cumulative response of monetary aggregates to terms-of-trade index innovations

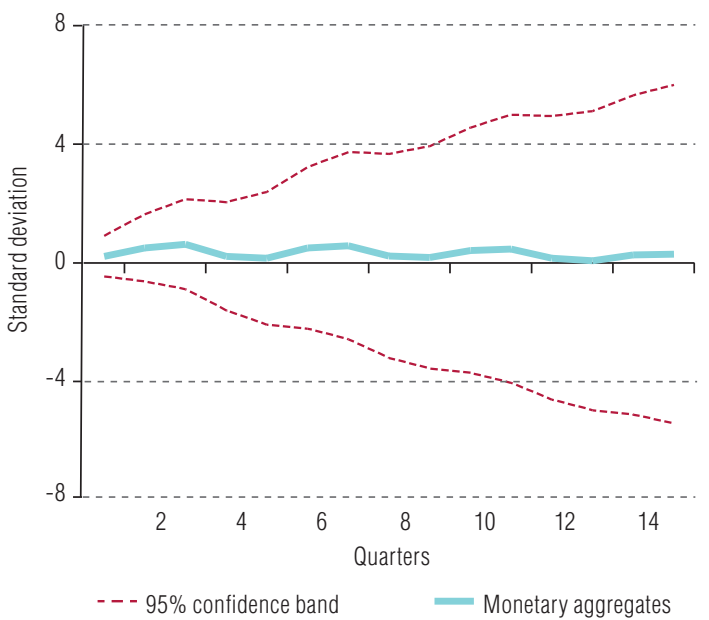

F. Cumulative response of prices to terms-of-trade index innovations

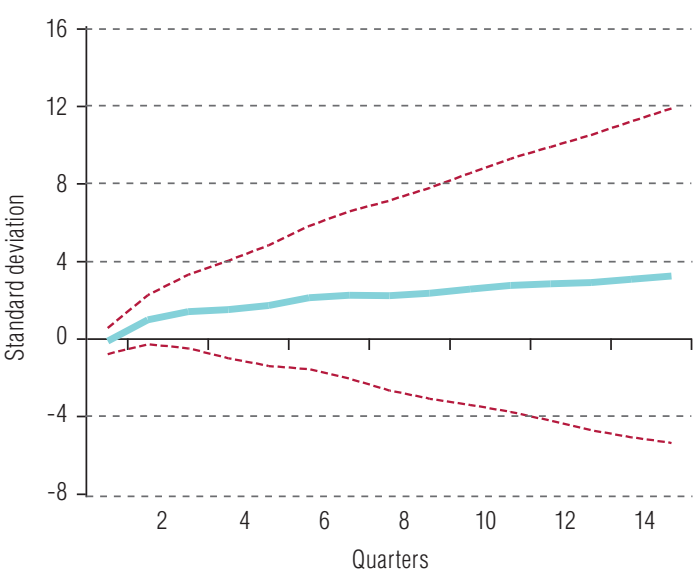

- - - $95 \%$ confidence band

- Prices

G. Cumulative response of total consumption to terms-of-trade index innovations

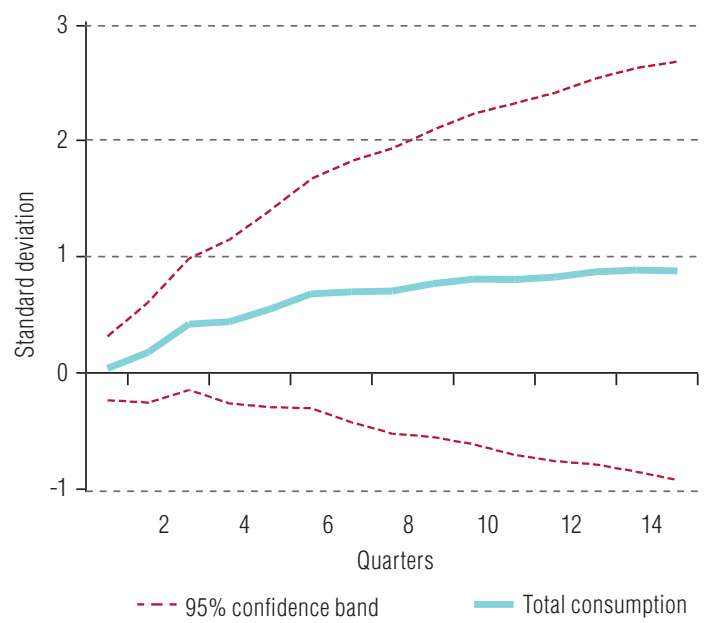

Source: Prepared by the authors.

The application of variance decomposition indicates that the terms of trade explain $6 \%$ of variance in GDP, $9 \%$ in investment, $10 \%$ in the trade balance, $2 \%$ in the real exchange rate, $5 \%$ in monetary aggregates, $5 \%$ in prices and $4 \%$ in total consumption. There were slight increases in comparison with the estimates of the model with four factors, mainly the trade balance.

Lastly, and with a view to isolating the effects of export and import prices, the second robustness test estimates the impulse response functions of the positive impulses generated by the export and import price indices, respectively. The results described in annex A3 indicate that a positive shock of the export price index generates positive and significant effects on economic activity, investment and the trade balance, and a negative and significant effect on the exchange rate. Moreover, the variance decomposition (see table 1 in section VI) shows that investment reflects the greatest variance (6\%) in light of a shock for the terms-of-trade index. Meanwhile, a positive shock for the import price index 
generates positive and significant effects on economic activity, investment, the exchange rate and prices. However, there were significant negative effects on the trade balance. On the basis of variance decomposition (see table 1), the greatest impact appears to have been felt by prices (7\%), followed by investment (5\%). Note that the results are similar to those obtained through the use of the main model. The export price index generates effects similar to the terms-of-trade index in terms of sign and duration.

\section{Conclusions}

The aim of this article is to analyse the impact of terms-of-trade shocks on the Colombian economy, in which commodities represent a large share of exports. It was based on the fact that previous studies had not analysed the persistence and impact of exogenous shocks resulting from variations in goods export and import prices on the different economic aggregates. Therefore, a large number of quarterly series for 2001-2016 were used to capture a considerable share of the different economic sectors in Colombia and thus make the most of the advantages of the FAVAR model to provide a more detailed explanation of the effect of these innovations on the economy.

The results show that terms-of-trade shocks have a significant impact on economic activity, investment, the real exchange rate and the trade balance. The characteristics of exported products and the openness of the economy play a key role in determining the impact, but in the case of Colombia it is evident that the terms of trade have a decisive effect on the economic variables described, especially investment. The use of a FAVAR model guarantees the analysis of impulse response functions of the macroeconomic series of interest, which show that a positive shock produces a boom in economic activity over four periods, appreciation of the real exchange rate over three periods and growth in the trade balance over six periods. Investment reflects an increase that lasts less than one quarter. Meanwhile, the variance decomposition analysis generates data showing that for 20 periods following the terms-of-trade shock, these terms of trade explain $8 \%$ of the variance in investment, $6 \%$ in the trade balance, $5 \%$ in economic activity and $1 \%$ in the real exchange rate.

\section{Bibliography}

Aguirre, E. (2011), "Essays on exchange rates and emerging markets", doctoral thesis, New York, Columbia University.

Ahmed, S. (2003), "Sources of economic fluctuations in Latin America and implications for choice of exchange rate regimes", Journal of Development Economics, vol. 72, No. 1, Amsterdam, Elsevier.

Andrews, D. and D. Rees (2009), "Macroeconomic volatility and terms of trade shocks", Research Discussion Paper, No. 2009-05, Reserve Bank of Australia (RBA).

Arteaga, C., J. Granados and J. Joya (2013), "El comportamiento del tipo de cambio real en Colombia: ¿explicado por sus fundamentales?", Ensayos sobre Política Económica, vol. 31, No. 72, Amsterdam, Elsevier.

Bai, J. and S. Ng (2002), "Determining the number of factors in approximate factor models", Econometrica, vol. 70, No. 1, Hoboken, Wiley.

Ben Zeev, N., E. Pappa and A. Vicondoa (2016), "Emerging economies business cycles: the role of the terms of trade revisited", Working Paper, No. 1610, Beerseba, Ben-Gurion University of the Negev.

Bernanke, B., J. Boivin and P. Eliasz (2005), "Measuring the effects of monetary policy: a factor-augmented vector autoregressive (FAVAR) approach", The Quarterly Journal of Economics, vol. 120, No. 1, Oxford, Oxford University Press.

Broda, C. (2004), "Terms of trade and exchange rate regimes in developing countries", Journal of International Economics, vol. 63, No. 1, Amsterdam, Elsevier.

Cano, G. and others (2012), "El mercado mundial del café y su impacto en Colombia", Working Paper, No. 710, Bogotá, Central Bank of Colombia. 
Castillo, P. and J. Salas (2012), Los términos de intercambio como impulsores de fluctuaciones económicas en economías en desarrollo: estudio empírico, Mexico City, Centre for Latin American Monetary Studies (CEMLA).

Chari, V., P. Kehoe and E. McGrattan (2008), "Are structural VARs with long-run restrictions useful in developing business cycle theory?”, Journal of Monetary Economics, vol. 55, No. 8, Amsterdam, Elsevier.

Charnavoki, V. and J. Dolado (2014), "The effects of global shocks on small commodity-exporting economies: lessons from Canada”, American Economic Journal: Macroeconomics, vol. 6, No. 2, Nashville, American Economic Association.

Dickey, D. and W. Fuller (1979), "Distribution of the estimators for autoregressive time series with a unit root", Journal of the American Statistical Association, vol. 74, No. 366a, Abingdon, Taylor \& Francis.

Fernández, A., A. González and D. Rodríguez (2015), "Sharing a ride on the commodities roller coaster: common factors in business cycles of emerging economies”, Working Paper, No. 915, Bogotá, Central Bank of Colombia.

Forni, M. and others (2005), "The generalized dynamic factor model: one-sided estimation and forecasting", Journal of the American Statistical Association, vol. 100, No. 471, Abingdon, Taylor \& Francis.

(2000), "The generalized dynamic-factor model: identification and estimation", The Review of Economics and Statistics, vol. 82, No. 4, Cambridge, MIT Press.

Garavito, A. and others (2011), "Construcción del índice de términos de intercambio para Colombia”, Working Paper, No. 639, Bogotá, Central Bank of Colombia.

Gaviria, A. (1993), "El ahorro privado y los términos de intercambio: el caso colombiano", Ensayos sobre Política Económica, vol. 12, No. 23, Bogotá, Central Bank of Colombia.

Geweke, J. (1978), The Dynamic Factor Analysis of Economic Time Series Models, University of Wisconsin.

Gómez, V. and A. Maravall (1998), "Seasonal adjustment and signal extraction in economic time series", Documento de Trabajo, No. 9809, Madrid, Bank of Spain.

Hernández, G. (2013), "Terms of trade and output fluctuations in Colombia", CEPAL Review, No. 110 (LC/G.2572-P), Economic Commission for Latin America and the Caribbean (ECLAC).

Izquierdo, A., R. Romero and E. Talvi (2008), "Booms and busts in Latin America: the role of external factors", Working Paper, No. 631, Washington, D.C., Inter-American Development Bank (IDB).

Jääskelä, J. and P. Smith (2013), "Terms of trade shocks: what are they and what do they do?", Economic Record, vol. 89, No. 285, Hoboken, Wiley.

Jenkins, R. (2011), "The 'China effect' on commodity prices and Latin American export earnings", CEPAL Review, No. 103 (LC/G.2487-P), Economic Commission for Latin America and the Caribbean (ECLAC).

Karagedikli, O. and G. Price (2012), "Identifying terms of trade shocks and their transmission to the New Zealand economy” [online] http://docs.business.auckland.ac.nz/Doc/Paper-10_Gael.pdf.

Mendoza, E. (1995), "The terms of trade, the real exchange rate, and economic fluctuations", International Economic Review, vol. 36, No. 1, Hoboken, Wiley.

Mumtaz, H. and P. Surico (2009), "The transmission of international shocks: a factor-augmented VAR approach", Journal of Money, Credit and Banking, vol. 41, No. s1, Hoboken, Wiley.

Ortiz, C. (2016), Diversificación productiva y crecimiento económico: enfoques teóricos y análisis del desarrollo socio-económico de Colombia, Cali, Universidad del Valle.

Parra, J. (2008), "Hechos estilizados de la economía colombiana: fundamentos empíricos para la construcción y evaluación de un modelo DSGE”, Working Paper, No. 509, Bogotá, Central Bank of Colombia.

Peláez, J. and L. Sierra (2016), "Does industrial employment react to movements in the real exchange rate? An empirical analysis for Colombia, 2000-2010", Latin American Journal of Economics, vol. 53, No. 1, Santiago, Pontifical Catholic University of Chile.

Pesaran, H. and Y. Shin (1998), "Generalized impulse response analysis in linear multivariate models", Economics Letters, vol. 58, No. 1, Amsterdam, Elsevier.

Phillips, P. and P. Perron (1988), "Testing for a unit root in time series regression", Biometrika, vol. 75, No. 2, Oxford, Oxford University Press.

Poncela, P., E. Senra and L. Sierra (2017), "Long-term links between raw materials prices, real exchange and relative de-industrialization in a commodity-dependent economy: empirical evidence of 'Dutch disease' in Colombia", Empirical Economics, vol. 52, No. 2, New York, Springer.

Roberts, M. and W. Schlenker (2013), "Identifying supply and demand elasticities of agricultural commodities: implications for the US ethanol mandate", The American Economic Review, vol. 103, No. 6, Nashville, American Economic Association.

Schmitt-Grohé, S. and M. Uribe (2015), "How important are terms of trade shocks?", NBER Working Paper, No. 21253, Cambridge, Massachusetts, National Bureau of Economic Research (NBER). 
Sierra, L. (2015), “¿Qué tanto afecta Asia a Latinoamérica?: el canal de las materias primas”, Las relaciones económicas entre América Latina y Asia: hacia la construcción de una nueva inserción internacional, M. de Miranda and J. Peláez (comps.), Cali, Pontificia Universidad Javeriana de Cali.

Sierra, L. and L. Manrique (2014), "A first approach to the impact of the real exchange rate on industrial sectors in Colombia", CEPAL Review, No. 114 (LC/G.2629-P), Santiago, Economic Commission for Latin America and the Caribbean (ECLAC).

Sinnott, E., J. Nash and A. de la Torre (2010), Natural resources in Latin America and the Caribbean: beyond booms and busts?, Washington, D.C., World Bank.

Spatafora, N. and A. Warner (1999), "Macroeconomic and sectoral effects of terms-of-trade shocks: the experience of the oil-exporting developing countries", IMF Working Paper, No. 99/134, Washington, D.C, International Monetary Fund (IMF).

Stock, J. and M. Watson (2011), "Dynamic factor models", Oxford Handbook of Economic Forecasting, M. Clements and D. Hendry (eds.), Oxford, Oxford University Press.

(2005), "Implications of dynamic factor models for VAR analysis", NBER Working Paper, No. 11467, Cambridge, Massachusetts, National Bureau of Economic Research (NBER).

(2002), "Macroeconomic forecasting using diffusion indexes", Journal of Business \& Economic Statistics, vol. 20, No. 2, Abingdon, Taylor \& Francis.

World Bank (2016), "Exports of goods and services (\% of GDP)" [online] https://data.worldbank.org/indicator/ NE.EXP.GNFS.ZS?locations $=$ CO.

(2000), Securing our Future in a Global Economy, Washington, D.C. 


\section{Annex A1}

The series were taken from the Bank of the Republic, the National Administrative Department of Statistics (DANE), the Ministry of Finance and Public Credit and the International Monetary Fund (IMF). The change in each series is outlined as follows: 1 - No change; 2 - Logarithm; 3 - First difference; 4 - First difference of the logarithm.

Table A1.1

Description of the variables of interest

\begin{tabular}{cllc}
\hline Number & Variable & Source & Change \\
\hline 1 & Terms-of-trade index & Bank of the Republic & 4 \\
\hline 2 & GDP & DANE & 4 \\
\hline 3 & Total consumption & DANE & 4 \\
\hline 4 & Gross fixed capital formation (Investment) & DANE & 4 \\
\hline 5 & Trade balance (Billions of pesos) & Bank of the Republic & 4 \\
\hline 6 & Exchange rate with respect to 18 IMF member countries & Bank of the Republic & 4 \\
\hline 7 & Total inflation & Bank of the Republic & 4 \\
\hline
\end{tabular}

Source: Prepared by the authors, on the basis of data from Bank of the Republic, National Administrative Department of Statistics (DANE), Ministry of Finance and Public Credit and International Monetary Fund (IMF).

Table A1.2

Description of the 129 series used

\begin{tabular}{clll}
\hline Number & Variable & Source & Change \\
\hline Economic activity at constant prices (Billions of pesos) & & DANE & 1 \\
\hline 1 & GDP growth & DANE & 4 \\
\hline 2 & Index of real manufacturing industry output & DANE & 4 \\
\hline 3 & Industrial goods output: grey cement (tons) & DANE & 4 \\
\hline 4 & Industrial goods output: assembled vehicles (quantity) & DANE & 2 \\
\hline 5 & Industrial goods output: sugar (tons) & DANE & 2 \\
\hline 6 & Government final consumption & DANE & 2 \\
\hline 7 & Household final consumption & DANE & 1 \\
\hline 8 & Consumption of durable goods (Percentage) & DANE & 1 \\
\hline 9 & Consumption of non-durable goods (Percentage) & DANE & 1 \\
\hline 10 & Consumption of semi-durable goods (Percentage) & DANE & 1 \\
\hline 11 & Consumption of services (Percentage) & DANE & 4 \\
\hline 12 & Domestic final demand & DANE & 4 \\
\hline 13 & Gross capital formation & DANE & 1 \\
\hline 14 & Gross capital formation: agriculture, forestry, hunting and fishing & DANE & 1 \\
\hline 15 & Gross capital formation: construction & DANE & 1 \\
\hline 16 & Gross capital formation: transport equipment & DANE & 1 \\
\hline 17 & Gross capital formation: machinery and equipment & DANE & 1 \\
\hline 18 & Gross capital formation: civil engineering works & DANE & 1 \\
\hline 19 & Gross capital formation: services & DANE & 1 \\
\hline 20 & Changes in inventories & Ministry of Finance and Public Credit & 4 \\
\hline 21 & Total domestic debt & Ministry of Finance and Public Credit & 4 \\
\hline 22 & Domestic debt: expenditure & Ministry of Finance and Public Credit & 2 \\
\hline 23 & Domestic debt: repayment & & \\
\hline
\end{tabular}


Table A1.2 (continued)

\begin{tabular}{|c|c|c|c|}
\hline Number & Variable & Source & Change \\
\hline \multicolumn{4}{|c|}{ External sector (Billions of pesos) } \\
\hline 24 & External debt & Ministry of Finance and Public Credit & 4 \\
\hline 25 & Total exports & DANE & 4 \\
\hline 26 & Coffee exports & DANE & 4 \\
\hline 27 & Coffee exports (metric tons) & DANE & 4 \\
\hline 28 & Coal exports & DANE & 4 \\
\hline 29 & Coal exports (metric tons) & DANE & 2 \\
\hline 30 & Nickel exports & DANE & 4 \\
\hline 31 & Nickel exports (metric tons) & DANE & 2 \\
\hline 32 & Exports of oil and its derivatives & DANE & 4 \\
\hline 33 & Exports of oil and its derivatives (metric tons) & DANE & 4 \\
\hline 34 & Total traditional exports & DANE & 4 \\
\hline 35 & Total non-traditional exports & DANE & 4 \\
\hline 36 & Total imports & DANE & 4 \\
\hline 37 & Imports of intermediate goods and commodities: agricultural sector & DANE & 4 \\
\hline 38 & Imports of intermediate goods and commodities: industrial sector & DANE & 4 \\
\hline 39 & Imports of intermediate goods and commodities: fuels & DANE & 4 \\
\hline 40 & Capital goods imports: agricultural sector & DANE & 4 \\
\hline 41 & Capital goods imports: industrial sector & DANE & 4 \\
\hline 42 & Capital goods imports: transport equipment & DANE & 4 \\
\hline 43 & Capital goods imports: construction materials & DANE & 4 \\
\hline 44 & Consumer goods imports: durable goods & DANE & 4 \\
\hline 45 & Consumer goods imports: non-durable goods & DANE & 4 \\
\hline 46 & Index of imported high-value goods & IMF & 4 \\
\hline \multicolumn{4}{|c|}{ Real exchange rate } \\
\hline 47 & Exchange rate, total trade: external trade data & Bank of the Republic & 4 \\
\hline 48 & Exchange rate, total trade: producer price index data & Bank of the Republic & 4 \\
\hline 49 & Exchange rate, non-traditional: external trade data & Bank of the Republic & 4 \\
\hline 50 & Exchange rate, non-traditional: producer price index data & Bank of the Republic & 4 \\
\hline 51 & Exchange rate, indicator of competitiveness in the United States market & Bank of the Republic & 4 \\
\hline \multicolumn{4}{|c|}{ Prices: consumer price index (CPI) } \\
\hline 52 & Total & DANE & 4 \\
\hline 53 & Food & DANE & 3 \\
\hline 54 & Communications & DANE & 3 \\
\hline 55 & Leisure & DANE & 3 \\
\hline 56 & Clothing & DANE & 3 \\
\hline 57 & Education & DANE & 4 \\
\hline 58 & Other expenditure & DANE & 4 \\
\hline 59 & Health & DANE & 4 \\
\hline 60 & Transport & DANE & 4 \\
\hline 61 & Housing & DANE & 4 \\
\hline 62 & Annual variation & Bank of the Republic & 3 \\
\hline 63 & Regulated goods & Bank of the Republic & 4 \\
\hline 64 & Regulated goods: annual variation & Bank of the Republic & 4 \\
\hline 65 & Tradable goods & Bank of the Republic & 4 \\
\hline 66 & Non-tradable goods & Bank of the Republic & 4 \\
\hline 67 & Non-tradable goods: annual variation & Bank of the Republic & 4 \\
\hline
\end{tabular}


Figure A1.2 (continued)

\begin{tabular}{|c|c|c|c|}
\hline Number & Variable & Source & Change \\
\hline \multicolumn{4}{|c|}{ Prices: producer price index (PPI) } \\
\hline 68 & Classification by economic use or purpose: capital goods & DANE & 4 \\
\hline 69 & Classification by economic use or purpose: final consumption & DANE & 4 \\
\hline 70 & Classification by economic use or purpose: intermediate consumption & DANE & 4 \\
\hline 71 & Classification by economic use or purpose: construction materials & DANE & 4 \\
\hline 72 & Domestic supply & DANE & 4 \\
\hline 73 & Domestic supply: agriculture, livestock, hunting, forestry and fishing & DANE & 4 \\
\hline 74 & Domestic supply: industry & DANE & 4 \\
\hline 75 & Domestic supply: mining & DANE & 4 \\
\hline 76 & Domestic production & DANE & 4 \\
\hline 77 & Domestic production: agriculture, livestock, hunting, forestry and fishing & DANE & 4 \\
\hline 78 & Domestic production: industry & DANE & 4 \\
\hline 79 & Domestic production: mining & DANE & 4 \\
\hline 80 & Origin: produced and consumed & DANE & 4 \\
\hline 81 & Origin: exported & DANE & 4 \\
\hline 82 & Origin: imported & DANE & 4 \\
\hline \multicolumn{4}{|c|}{ Monetary aggregates (Billions of pesos) } \\
\hline 83 & Monetary base: cash & Bank of the Republic & 4 \\
\hline 84 & Monetary base: bank reserves & Bank of the Republic & 4 \\
\hline 85 & Total monetary base & Bank of the Republic & 4 \\
\hline 86 & Bonds & Bank of the Republic & 4 \\
\hline 87 & Current accounts: private sector & Bank of the Republic & 4 \\
\hline 88 & Current accounts: public sector & Bank of the Republic & 4 \\
\hline 89 & Current accounts: total & Bank of the Republic & 4 \\
\hline 90 & Near money: savings accounts & Bank of the Republic & 4 \\
\hline 91 & Near money: certificates of deposit & Bank of the Republic & 2 \\
\hline 92 & Near money: total & Bank of the Republic & 4 \\
\hline 93 & Fiduciary deposits & Bank of the Republic & 4 \\
\hline 94 & Demand deposits & Bank of the Republic & 4 \\
\hline 95 & M1 & Bank of the Republic & 4 \\
\hline 96 & M2 & Bank of the Republic & 4 \\
\hline 97 & M3 & Bank of the Republic & 4 \\
\hline 98 & $\begin{array}{l}\text { Current account deposits + near money + bonds + demand deposits } \\
+ \text { repurchase agreements + fiduciary deposits + certificates of deposit: } \\
\text { total liabilities to be covered by reserves }\end{array}$ & Bank of the Republic & 4 \\
\hline \multicolumn{4}{|c|}{ Total national employment } \\
\hline 99 & Unemployed (Thousands) & DANE & 4 \\
\hline 100 & Inactive (Thousands) & DANE & 4 \\
\hline 101 & Employed (Thousands) & DANE & 4 \\
\hline 102 & Unemployment rate & DANE & 4 \\
\hline 103 & Participation rate & DANE & 4 \\
\hline 104 & Employment rate & DANE & 4 \\
\hline \multicolumn{4}{|c|}{ Non-financial public sector (Billions of pesos) } \\
\hline 105 & Deficit or surplus & Ministry of Finance and Public Credit & 3 \\
\hline 106 & Domestic financing & Ministry of Finance and Public Credit & 3 \\
\hline 107 & Deficit or surplus, non-financial public companies & Ministry of Finance and Public Credit & 1 \\
\hline 108 & Expenditure & Ministry of Finance and Public Credit & 4 \\
\hline 109 & Income & Ministry of Finance and Public Credit & 4 \\
\hline 110 & Interest & Ministry of Finance and Public Credit & 4 \\
\hline 111 & External financing & Ministry of Finance and Public Credit & 1 \\
\hline
\end{tabular}


Table A1.2 (concluded)

\begin{tabular}{llll}
\hline Number & Variable & Source & Change \\
\hline Foreign direct investment flows into Colombia (Billions of pesos) & & 3 \\
\hline 112 & Oil sector & Bank of the Republic & 4 \\
\hline 113 & Manufacturing & Bank of the Republic & 4 \\
\hline 114 & Total foreign direct investment flows & Bank of the Republic & 1 \\
\hline 115 & Agriculture, hunting, forestry and fishing & Bank of the Republic & 1 \\
\hline 116 & Commerce, restaurants and hotels & Bank of the Republic & 1 \\
\hline 117 & Construction & Bank of the Republic & 1 \\
\hline 118 & Electricity, gas and water & Bank of the Republic & 1 \\
\hline 119 & Mines and quarries & Bank of the Republic & 1 \\
\hline 120 & Financial and business services & Bank of the Republic & 1 \\
\hline 121 & Community-based services & Bank of the Republic & 1 \\
\hline 122 & Transport, storage and communications & Bank of the Republic & 2 \\
\hline 123 & Subtotal, remaining sectors & Bank of the Republic & 3 \\
\hline Interest rates & & & 3 \\
\hline 124 & Monthly deposit interest rate & Bank of the Republic & 1 \\
\hline 125 & External interest rate: preferential rate & Bank of the Republic & 1 \\
\hline 126 & Lending rate of the Bank of the Republic & Bank of the Republic & 1 \\
\hline 127 & Total lending rate & Bank of the Republic & 1 \\
\hline 128 & Intervention rate of the Bank of the Republic & Bank of the Republic & \\
\hline 129 & Lending rate excluding treasury operations & Bank of the Republic & \\
\hline
\end{tabular}

Source: Prepared by the authors, on the basis of data from Bank of the Republic, National Administrative Department of Statistics (DANE), Ministry of Finance and Public Credit and International Monetary Fund (IMF). 


\section{Annex A2}

Table A2.1 contains information on the number of lags according to the selection criterion. Three lags were used given that the model for this value is robust and consistent in the evaluation of the assumptions for residuals.

Table A2.1

Lag selection criteria

\begin{tabular}{lccccc}
\hline Criterion & LRT & FPE & AIC & SC & HQ \\
\hline Number of lags & 4 & 4 & 4 & 0 & 1 \\
\hline
\end{tabular}

Source: Prepared by the authors

Note: LRT: likelihood ratio test; FPE: final prediction error; AIC: Akaike information criterion; SC: Schwarz information criterion; HQ: Hannan-Quinn information criterion.

Table A2.2 shows the test for autocorrelation (Lagrange Multiplier test) in residuals.

Table A2.2

Test for autocorrelation (Lagrange Multiplier test)

\begin{tabular}{ccc}
\hline Period & Lagrange Multiplier statistic (LM-Stat) & p-value \\
\hline 1 & 79.74127 & 0.0886 \\
\hline 2 & 75.90989 & 0.1464 \\
\hline 3 & 69.67821 & 0.2924 \\
\hline 4 & 66.85996 & 0.3791 \\
\hline 5 & 67.29289 & 0.3651 \\
\hline 6 & 47.04699 & 0.9447 \\
\hline 7 & 74.02127 & 0.1836 \\
\hline
\end{tabular}

Source: Prepared by the authors.

Note: Null hypothesis: there is no correlation between the residuals. 


\section{Annex A3}

Figure A3.1

Accumulated impulse response functions of economic activity, investment, trade balance, exchange rate, prices, monetary aggregates and total consumption to generalized one standard deviation innovations in the export price index

Accumulated response to Cholesky one standard deviation innovations \pm 2

A. Response of economic activity to EPI

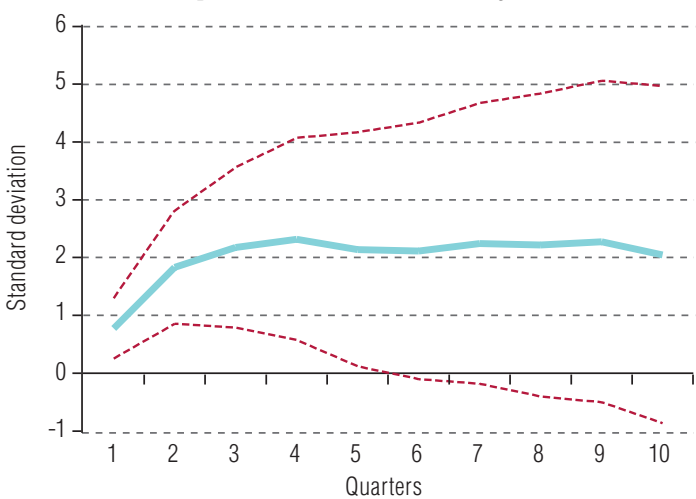

- - - 95\% confidence band

$$
\text { Economic activity }
$$

C. Response of the trade balance to EPI

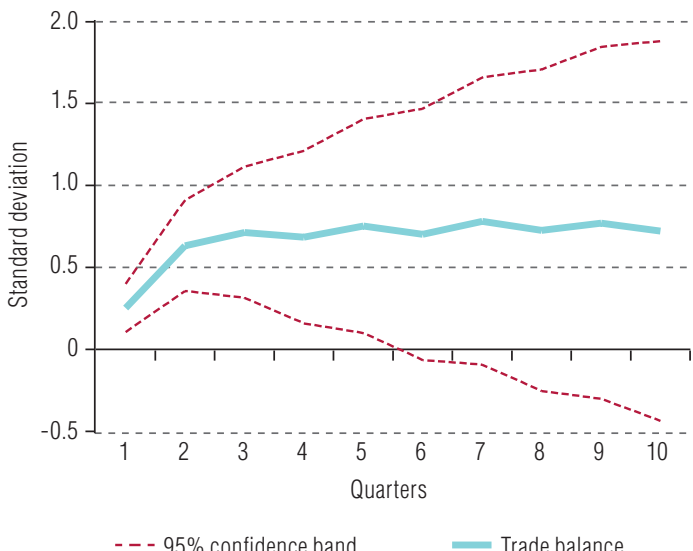

B. Response of investment to EPI

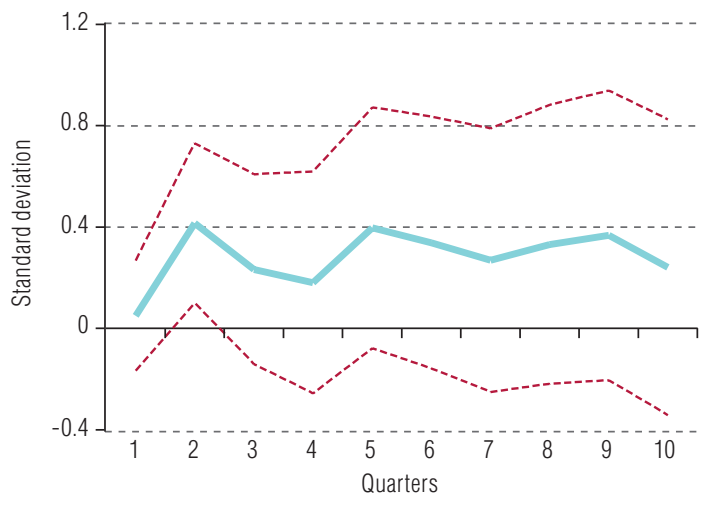

- - - 95\% confidence band

Investment

D. Response of the exchange rate to EPI

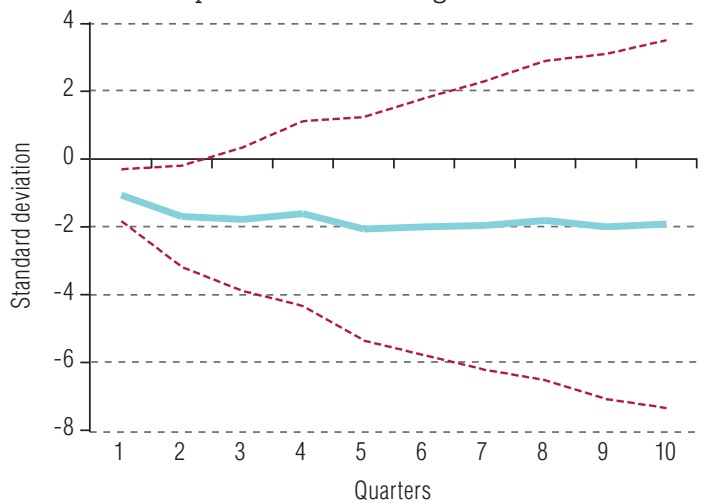

- - - 95\% confidence band _ Exchange rate 
Figure A3.1 (concluded)

E. Response of monetary aggregates to EPI

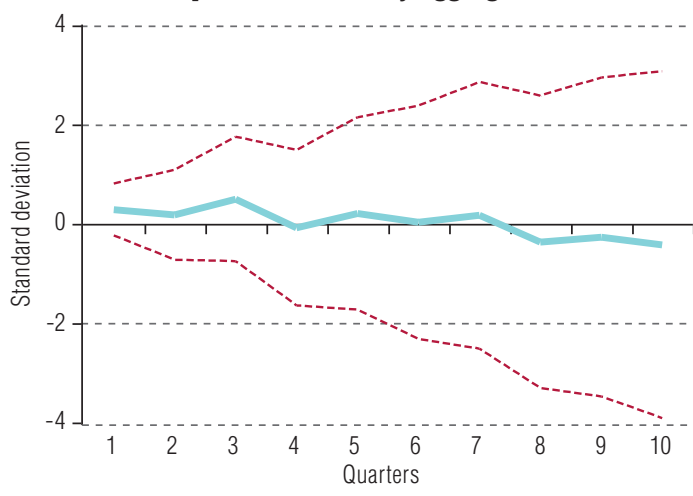

- - - 95\% confidence band

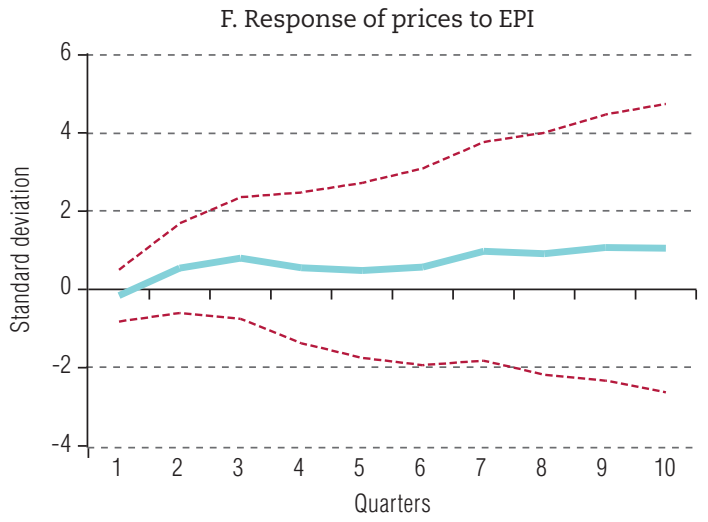

- - - 95\% confidence band $\quad$ Prices

G. Response of total consumption to EPI

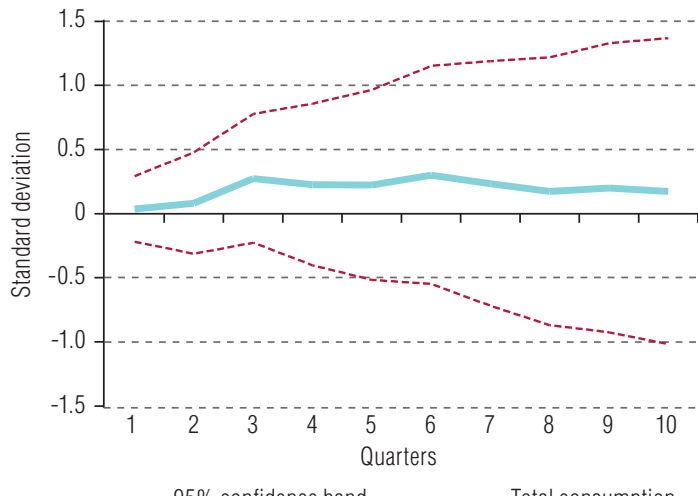

Source: Prepared by the authors.

Note: $\quad E P I$ is the export price index.

Figure A3.2

Accumulated impulse response functions of economic activity, investment, trade balance, exchange rate, prices, monetary aggregates and total consumption to generalized one standard deviation innovations in the import price index

Accumulated response to Cholesky one standard deviation innovations \pm 2

A. Response of economic activity to IPI

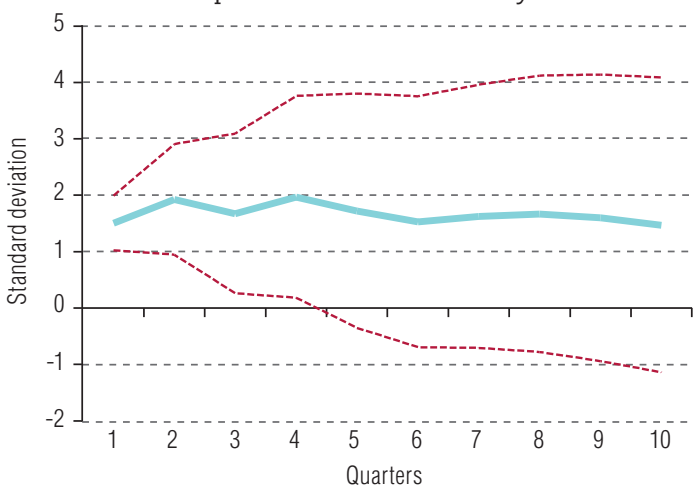

- - - 95\% confidence band $\quad$ Economic activity
B. Response of investment to IPI

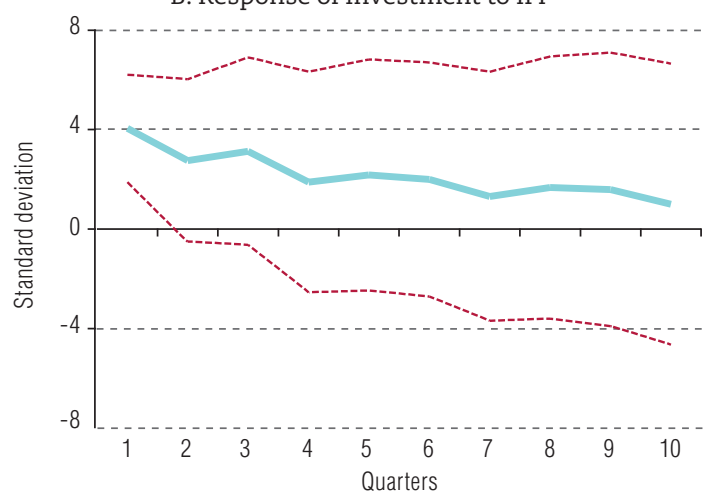

- - - 95\% confidence band _ Investment 
Figure A3.2 (concluded)

C. Response of the trade balance to IPI

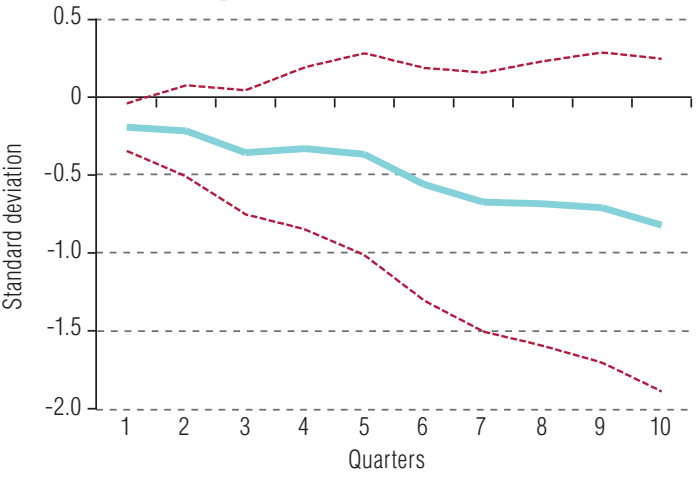

- - - 95\% confidence band

- Trade balance

E. Response of monetary aggregates to IPI

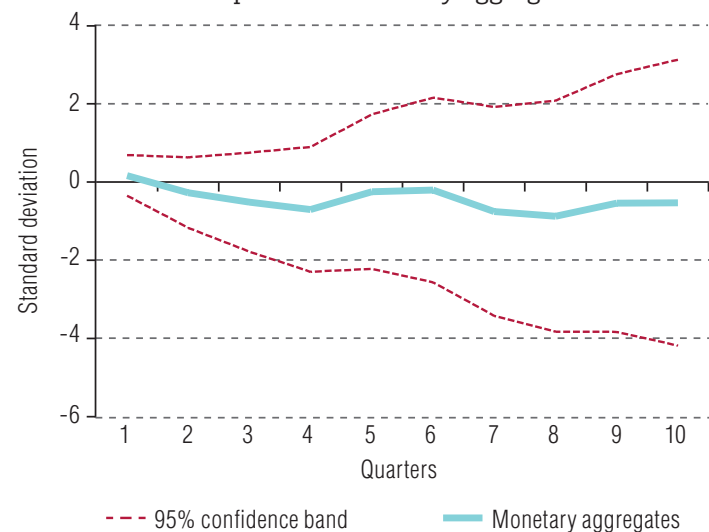

D. Response of the exchange rate to IPI

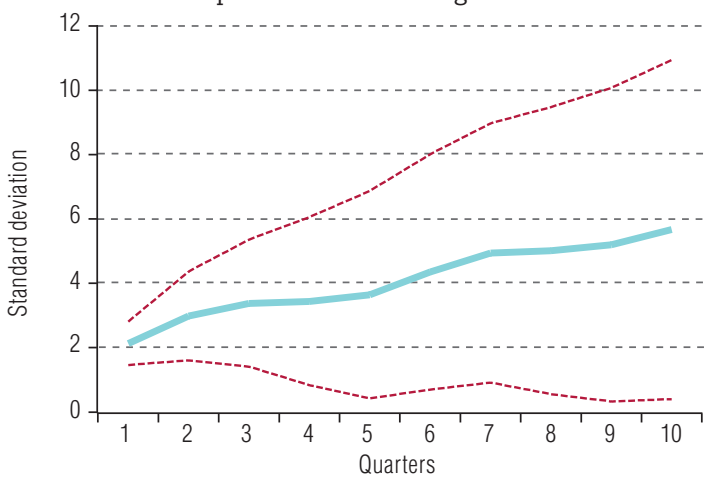

- - - 95\% confidence band - Exchange rate

F. Response of prices to IPI

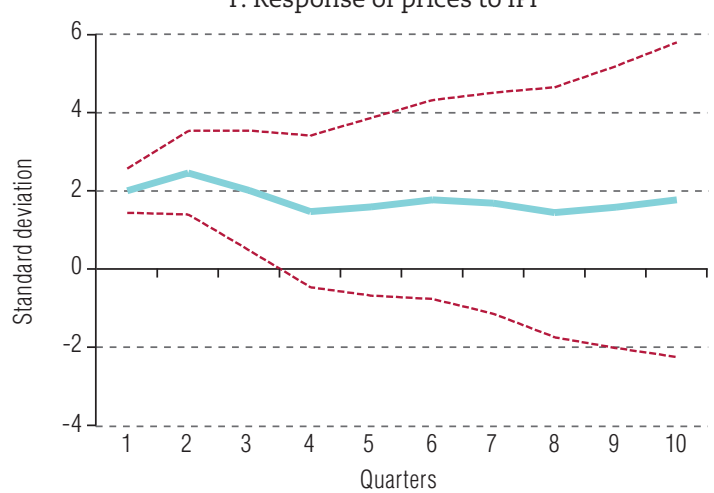

- - - 95\% confidence band

Prices

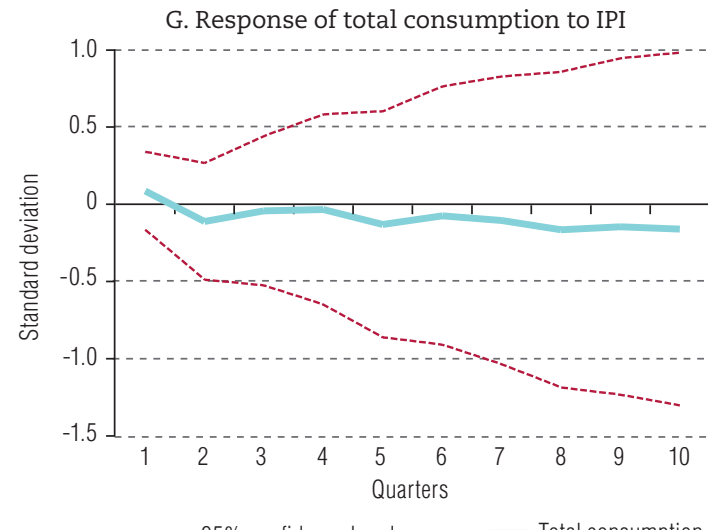

Source: Prepared by the authors.

Note: IPI is the import price index. 
Table A3.1

Variance decomposition of selected variables of interest

\begin{tabular}{lcc}
\hline Variable & $\begin{array}{c}\text { Percentage of variance explained } \\
\text { by export price index }\end{array}$ & $\begin{array}{c}\text { Percentage of variance explained } \\
\text { by import price index }\end{array}$ \\
\hline Economic activity (GDP) & 4.00 & 2.00 \\
\hline Total consumption & 3.00 & 3.00 \\
\hline Monetary aggregates & 2.00 & 3.00 \\
\hline Trade balance & 4.00 & 1.00 \\
\hline Prices (inflation) & 1.00 & 7.00 \\
\hline Real exchange rate & 1.00 & 2.00 \\
\hline Investment & 6.00 & 5.00 \\
\hline
\end{tabular}

Source: Prepared by the authors. 